\title{
CONVERTIBILITY, CURRENCY CONTROLS AND THE COST OF CAPITAL IN WESTERN EUROPE, 1950-1999
}

\author{
HANS-JOACHIM VOTH* ${ }^{*}$ \\ Economics Department, UPF, Barcelona, Spain
}

\begin{abstract}
For most of the post-war period, Europe's capital markets remained largely closed to international capital flows. This paper explores the costs of this policy. Using an event-study methodology, I examine the extent to which restrictions of current and capital account convertibility affected stock returns. The delayed introduction of full currency convertibility increased the cost of capital. Also, a string of measures designed to reduce capital mobility before the ultimate collapse of the Bretton Woods System had considerable negative effects. These findings offer an explanation for the mounting evidence suggesting that capital account liberalization facilitates growth. Copyright (C) 2003 John Wiley \& Sons, Ltd.

JEL CODE: F21; G15
\end{abstract}

KEY WORDS: Cost of capital; liberalization; current account; capital account; convertibility

The Asian crisis of 1997/98 provided fresh arguments for critics of free capital movement. The severity of the contraction in East Asia appeared to suggest that some form of capital controls could help to isolate economies from volatile short-term capital flows (Edwards, 1998). Paul Krugman (1999) put it succinctly: '... we will have to turn the clock at least part of the way back: to limit capital flows for countries that are unsuitable for either currency unions or free floating'. Limiting capital outflows - as implemented by Malaysia, for example - is the primary focus of Krugman's proposal (Krugman, 1998). Restrictions on inflows have been advocated as an alternative (Eichengreen, 1999). The case of Chile is often cited as an example of the successful implementation of capital controls, combining reduced volatility with strong macroeconomic performance (Massad, 1998). In particular, the authorities appear to have had some success in avoiding contagion from emerging market crises (Edwards, 1999). Even in industrialized countries, the markedly higher volatility of real interest rates following the demise of the Bretton Woods System led to calls for a reintroduction of pegs vis-á-vis the dollar. ${ }^{1}$

Arguments in favour of greater restrictions have partly gained in influence because, until recently, there was little evidence that they do any harm. Using standard growth regressions, Rodrik (1998) found that capital controls have no measurable effect on growth, investment or inflation. On balance, he argues that unfettered capital flows create significant risks without clearly discernible benefits. ${ }^{2}$ Indirectly, work on the link between finance and growth also appears to strengthen this conclusion. Levine and Zervos (1998a,b) argued that while stock market size and liquidity, and the size of the banking sector have predictive power for future growth, the degree of integration into the world capital market does not. ${ }^{3}$ The post-war experience of Western Europe has also been used to argue that financial repression, when used to stabilize exchange rates, may even produce important benefits. Spectacular rates of growth during the years 1950-73

\footnotetext{
*Correspondence to: Hans-Joachim Voth, Economics Department, UPF, C/Ramon Trias Fargas 25-27, E-08005 Barcelona, Spain.

${ }^{\dagger}$ E-mail:joachim.voth@econ.upf.es

Contract/grant sponsor: CREI.

Contract/grant sponsor: the Leverhulme Trust.

Contract/grant sponsor: the Spanish Education Ministry (MCYT).
}

Copyright (C) 2003 John Wiley \& Sons, Ltd. 
coincided with numerous restrictions on capital mobility. Wyplosz (1999), for example, argues that this was no accident. Capital controls, combined with credit ceilings and fixed exchange rates, contributed as much as $0.9 \%$ p.a. to economic growth during the period $1960-95$. This is all the more remarkable since evidence from Italy, France and Belgium suggests that capital controls, while successful in reducing real interest rates, also raised the volatility of nominal interest rates and reduced competition in the financial sector (Wyplosz, 1999).

Support for a positive effect of capital account liberalization comes from recent studies using a more nuanced indicator of capital control intensity developed by Quinn (Arteta et al., 2001; Edison et al., 2002; Edwards, 2001; Eichengreen, 2001; Quinn, 1997). Edwards (2001) argues that financial liberalization is beneficial for more advanced countries, but that emerging markets may not profit from a free capital account. Arteta et al. (2001) emphasize that the sequencing of reform matters, and that beneficial effects can be expected if capital account convertibility follows trade liberalization. In contrast, Klein and Olivei (1999) find that measures of financial depth normally associated with growth only benefit from liberalization in developing countries. No such association is apparent for more advanced countries (Klein and Olivei, 1999).

In tracing the effects of capital account liberalizations, interest has primarily focused on the effects of capital controls on the level and volatility of interest rates. ${ }^{4}$ In cases where capital outflows are restricted - the vast majority of cases-interest rates are lowered artificially. The benefits of lower rates have to be weighed against the potential inefficiencies of credit rationing (Wyplosz, 1999). Only if inflows are stifled are interest rates driven above their equilibrium levels, and it becomes relatively easy to find negative effects. Edwards (1999) is one of the few empirical contributions examining the consequences of lower capital mobility. He concludes that, in Chile between 1991 and 1998, capital controls burdened small and medium-size firms with markedly higher rates of interest. At the same time, there appears to have been no clear benefit in terms of lower interest rate volatility. ${ }^{5}$

In this debate, one factor has received almost no attention - the possibility that capital controls may increase the cost of equity finance. From a theoretical point of view, the consequences should be negative. Greater opportunities for diversification of risk normally allow countries joining the world capital market to reduce their cost of equity capital. Country-specific risk can partly be diversified. Under fairly general assumptions, Stulz (1999) shows that, if standard IAPM holds, globalization will reduce the equity premium in a country. Unless the covariance of a country's equity returns with the world portfolio is very high, opportunities for risk diversification should ensure that the cost of capital falls as a result of greater integration into the world equity market (Stulz, 1999). Using an event-study approach, a growing literature suggests that the empirical implications are borne out. The type of liberalizations considered typically include the introduction of country funds, ADR listings, or the revocation of limits on foreign ownership. ${ }^{6}$ Recent studies (Bekaert and Harvey, 2000; Henry, 2000) demonstrate that stock market liberalizations are systematically followed by large positive equity returns. As long as future cash flow is constant, this indicates a reduction in the cost of equity capital. Evidence that dividend yields fall as a result of liberalizations reinforces this finding (Bekaert and Harvey, 2000). Also, changes in the investability index compiled by the IFC tend to have a significant impact on the yield of equities. Reductions of restrictions often lead to large capital gains (Bekaert, 1995). In addition to reductions in the cost of capital via lower risk, there are also good theoretical reasons to assume that integration into the world capital market facilitates investment in projects that are more risky, but offer greater pay-offs (Obstfeld, 1994). One recent contribution that explicitly examines the connection between controls and the cost of capital is Kaplan and Rodrik (2001). They argue that the imposition of capital controls actually facilitated an early recovery of the Malaysian stock market, suggesting a reduction in the cost of capital (Kaplan and Rodrik, 2001). Their results, however, depend on a highly idiosyncratic way of controlling for the general timing of recovery in Asia. $^{7}$

Stock market liberalizations such as the introduction of ADRs on foreign exchanges, country funds, etc. are amongst the most prominent measures a country can adopt to open its capital market to the world. However, they only represent one part of a wider spectrum of steps that can be taken. The introduction of current account convertibility normally represents a first step towards full-scale liberalization. Once import 
controls are revoked, cross-border capital flows cannot be avoided altogether; over- and under-invoicing for imports and exports can easily be used to undermine the effectiveness of capital controls (Eichengreen, 1996). We should therefore expect to find that some of the effects documented in the case of fully fledged liberalizations are already present when current account convertibility is introduced. A related question is if measures to restrict capital flows have the predicted negative consequences. In this paper, I use the experience of Western Europe to examine the consequences of exchange and capital controls for the cost of capital. Since rapid post-war growth in these countries has been used as evidence that financial repression can actually have positive effects, it is a particularly interesting historical episode to examine (Wyplosz, 1999, 2000). Also, the more successful interventions carried out by these countries created large distortions, both by the standards of the time and in a long-term perspective (Dooley and Isard, 1980). I employ eventstudy methods to show that the introduction of current and capital account convertibility led to significant reductions in the cost of capital in post-war Western Europe. This paper then examines the effect of a growing number of capital controls that European countries enforced in the final years of the Bretton Woods System. These had considerable adverse effects on the cost of equity finance.

I begin by describing the history of current and capital account liberalization in Europe between 1950 and 1995. Section 2 analyses the effect of current account liberalization. Section 3 examines the consequences of capital controls in the late 1960s and early 1970s, and Section 4 concludes.

\section{LIBERALIZATION OF CAPITAL AND CURRENCY MOVEMENTS IN EUROPE, 1950-1995}

The Bretton Woods accords promised a return to full currency convertibility within five years of the IMF's founding (Eichengreen, 1996). At the same time, the free movement of capital was not part of the initial design. In the discussions leading up to the Bretton Woods conference in 1944, the British delegate, John M. Keynes, argued strongly that international capital mobility should be severely curtailed as part of the 'new financial architecture'. With memories of the destabilizing influence that cross-border capital flows had had in the interwar years still fresh, he wrote: 'Nothing is more certain than that the movement of capital funds must be regulated.... ${ }^{8}$ The British view largely prevailed, and the IMF statutes granted each member country the right to control capital movements as it saw fit. In his closing address, the US Secretary of the Treasury, Henry Morgenthau, hailed the success of the Bretton Woods conference in 'driv[ing] ... the usurious money lenders from the temple of international finance'. ${ }^{9}$

After the disastrous experience with Britain's 1947 attempt to make sterling convertible, even current account liberalization was no longer on the agenda. The USA stopped pressing for progress amongst her European allies. Nonetheless, reconstructing trading links was vital if Europe was to recover from the consequences of WW2. Almost all European countries ran trade deficits with the United States, as a result of capital goods imports needed for reconstruction, thus creating what was known as the 'dollar shortage'. Also, trade within Europe was hampered by a lack of currency reserves, making it impossible for countries to run temporary deficits. After a number of largely unsuccessful schemes to resolve the impasse in interEuropean trade, the European Payments Union was introduced in 1950 (Eichengreen, 1993). This provided for a system of multilateral netting arrangements, administered by the BIS in Basle, and allowed for the provision of credit. Beyond a certain limit (initially set at $20 \%$ of 1949 trade volume), debts had to be settled in either gold or dollars. ${ }^{10}$ It proved largely successful in restoring trading links within Europe, and in averting balance of payment crises when deficits rose (Temin, 1995). There is also some evidence that it helped to promote trade with non-EPU members (Eichengreen, 1993). The system was intended to operate for no more than two years. In the end, it remained in place until 1958. It was not before January 1959 that the majority of European countries returned to full currency convertibility, with countries like France delaying by a few more months (Bakker, 1993).

Liberalization of trade under the EPU proceeded by reducing the number of goods for which import licences were required. In the case of temporary imbalances, countries could halt or even revoke liberalization. With a balance of payments crisis looming, Germany for example did so in February 1951 (Kaplan and Schleiminger, 1989). Until the end, however, capital flows were all but 
impossible. Once currency markets opened, however, countries could no longer avoid in- and outflows of capital altogether. ${ }^{11}$

Nonetheless, the available evidence suggests that monetary authorities retained a good deal of control over capital flows. Obstfeld documents that during the 1960s, deviations from covered interest parity remained substantial. He finds an average differential of $2 \%$ for Britain and $1 \%$ for Germany. ${ }^{12}$ Comparisons of on- and offshore rates also indicate that capital controls remained effective-Eurosterling interest rates were on average 78 basis points higher than British rates, while Eurodeutschmark interest rates were 40 bp lower (Marston, 1993). A wide range of instruments was available to governments trying to isolate their economies from foreign capital flows. These took three principal forms. First, administrative controls can make all cross-border flows illegal if they have not been authorized previously. ${ }^{13}$ Second, states can impose taxes on capital in- or outflows in a number of forms. In the early 1970s, for example, Germany required banks to deposit a certain percentage of the increase in their foreign liabilities at zero interest with the Bundesbank. This was combined with a cash reserve requirement (Bakker, 1993). Third, states can operate dual or multiple exchange rate regimes. Current account transactions would be settled at one exchange rate, and capital account transactions at another. ${ }^{14}$ Belgium, France and Italy used dual market mechanisms as a way of controlling capital flows at different times.

\section{THE EFFECTS OF LIBERALIZATION}

In the empirical part of this paper, we use two methods to analyse the consequences of liberalizations and capital controls. Many studies that examine the effect of stock market liberalizations on the cost of capital have used event studies. We follow this approach here. Our results can thus easily be compared with those from studies of recent liberalizations in the Third World. Event studies are not without difficulties, however. Determining the relevant dates is no easy matter. Also, announcement effects may be strong, resulting in a stock market reaction prior to implementation that tends to obscure the true impact of interventions and regulatory changes. These difficulties cannot be avoided altogether, even if careful examination of the historical context and the use of alternative sets of dates can go some way towards addressing these issues. ${ }^{15}$

We augment this approach by using a measure widely accepted as a good proxy for the effectiveness of capital controls - the spread between on- and offshore interest. ${ }^{16}$ There is substantial evidence that, the longer capital controls are in place, the less effective they become. ${ }^{17}$ While indices of regulatory intervention may be constant, effective constraints on capital mobility may be withering away. This should be reflected in the extent to which capital controls suceed in driving a 'wedge' between domestic and Euromarket interest rates (Marston, 1995). There are three benefits of replacing the dummy variables for capital and current account convertibility with a continuous variable. First, it avoids issues of timing and the problem of announcement dates versus implementation. Second, these variables offer greater identifying variance. Third, we are using a more meaningful direct measure of the extent to which controls affected capital mobility.

Under what conditions is integration into the world capital market beneficial? Stulz (1999) shows that a necessary and sufficient condition for a reduction in the equity premium is:

$$
\frac{\sigma_{s}}{\sigma_{w}}>\rho
$$

where $\sigma$ is the variance of excess returns in a small country and the world, and $\rho$ is the correlation coefficient of returns on the small country portfolio and the world portfolio. If, as Edwards (1999) argues, the abolition of controls increases stock market volatility, this condition needs to be recast. Let us assume that volatility increases by a factor $\lambda$, where $\lambda>1$. Then, if $\sigma_{s}$ denotes the variance of returns in the small country before liberalization, the equity premium will fall if:

$$
\frac{\sigma_{s}}{\rho \sigma_{w}}>\lambda
$$

as long as there is no change in the riskless rate. Based on equation (2), we can calculate the critical value $\lambda^{*}$ above which the cost of equity capital in any one country would actually increase as a result of capital 
market integration. Table 1 gives some descriptive statistics, while Table 2 compares stock market volatility before and after current account liberalization. ${ }^{18}$

Based on correlations in the post-integration phase and the variances in the pre-integration phase, we calculate critical values for $\lambda$. For all periods, the actual change in volatility $\lambda$ is considerably below $\lambda^{*}$.

This raises the question of how much - if any-of the increase in volatility can be attributed to increasing market integration. To examine this issue more closely, we estimate a set of GARCH models in Appendix A. These demonstrate clearly that current and capital account liberalizations did not contribute significantly to the volatility of equity returns. Note that these results are in line with the findings of Bekaert and Harvey (2000) for the case of emerging markets.

To estimate the effects of liberalization measures, we follow the basic set-up used by Henry (2000) and estimate the following equation:

$$
R_{i t}=\alpha_{i}+\gamma_{1} \text { Liberalize }+\beta R_{t}^{U S}+\gamma_{2} \pi_{i t}+\gamma_{3} I_{i t}+\varepsilon_{i t}
$$

where $R_{i t}$ is the continuously compounded monthly real return in domestic currency in country $i$ at time $t$, $R^{U S}$ is the US stock market return, $\pi$ is the monthly rate of inflation, and $I$ is the change in the index of monthly industrial production. ${ }^{19}$ The use of a fixed effects model with country-specific intercepts is justified by evidence that average long-run equity returns vary from country to country. ${ }^{20}$ Liberalize is a dummy variable set equal to 1 for the 12-month period centred on the implementation month (starting with the fifth month before implementation, and ending with the sixth month afterwards). If $T^{*}$ is the implementation month, our event window extends from $T^{*}-5$ to $T^{*}+6$, giving 12 months in all. Extending the period during which the dummy is set to 1 so as to include the announcement date is common practice (MacKinlay, 1997). Given that markets only began to operate again, we may also expect adjustment to take some time, even after implementation. The sensitivity of our results with respect to the event window is tested below. ${ }^{21}$

Table 1. Descriptive statistics, monthly stock market returns

\begin{tabular}{|c|c|c|c|c|c|}
\hline & Germany & France & US & Italy & UK \\
\hline \multicolumn{6}{|l|}{ 1950:08-1958:12 } \\
\hline mean & $1.29 \%$ & $0.65 \%$ & $0.5 \%$ & $0.85 \%$ & $-0.03 \%$ \\
\hline std. dev. & $4.20 \%$ & $5.5 \%$ & $2.9 \%$ & $4.0 \%$ & $4.5 \%$ \\
\hline corr. with US & 0.12 & 0.31 & 1 & 0.26 & 0.26 \\
\hline \multicolumn{6}{|l|}{ 1959: 01-1972:12 } \\
\hline mean & $0.15 \%$ & $0.00 \%$ & $0.24 \%$ & $-0.17 \%$ & $0.32 \%$ \\
\hline std. dev. & $4.2 \%$ & $4.48 \%$ & $3.23 \%$ & $4.8 \%$ & $3.8 \%$ \\
\hline corr. with US & 0.25 & 0.27 & 1 & 0.19 & 0.37 \\
\hline \multicolumn{6}{|l|}{ 1973:01-1999:09 } \\
\hline mean & $0.32 \%$ & $0.43 \%$ & $0.32 \%$ & $0.14 \%$ & $0.09 \%$ \\
\hline std. dev. & $4.1 \%$ & $6.9 \%$ & $3.7 \%$ & $6.5 \%$ & $4.85 \%$ \\
\hline corr. with US & 0.31 & 0.41 & 1 & 0.35 & 0.58 \\
\hline
\end{tabular}

Table 2. Changes in volatility

\begin{tabular}{|c|c|c|c|c|c|c|c|c|}
\hline & \multicolumn{4}{|c|}{ Period 1-Period 2} & \multicolumn{4}{|c|}{ Period 2-Period 3} \\
\hline & Germany & France & Italy & UK & Germany & France & Italy & UK \\
\hline$\sigma_{s}$ & $4.2 \%$ & $5.5 \%$ & $4.0 \%$ & $4.5 \%$ & $4.2 \%$ & $4.48 \%$ & $6.5 \%$ & $3.8 \%$ \\
\hline$\sigma_{w}$ & $2.9 \%$ & $2.9 \%$ & $2.9 \%$ & $2.9 \%$ & $3.2 \%$ & $3.2 \%$ & $3.2 \%$ & $3.2 \%$ \\
\hline$r$ & 0.25 & 0.27 & 0.19 & 0.37 & 0.31 & 0.41 & 0.35 & 0.58 \\
\hline$\lambda^{*}$ & 5.79 & 7.02 & 7.26 & 4.19 & 4.19 & 3.38 & 4.25 & 2.03 \\
\hline$\lambda$ & 1.00 & 0.81 & 1.2 & 0.84 & 0.98 & 1.54 & 1.35 & 1.28 \\
\hline
\end{tabular}


Abnormal returns during the introduction of current account convertibility were large, and are statistically significant at the $1 \%$ level (Table 3). ${ }^{22}$ For the whole event window, we calculate cumulative abnormal returns of between $23 \%$ and $34 \%$ as a result of the introduction of current account convertibility. This is very similar to the effects found by Henry (2000) in the case of direct stock market liberalizations such as ADR listing and the introduction of country funds. He estimates monthly returns of $4.7 \%$ over a period of eight months, giving a cumulative return of $38 \%$. The significance and magnitude of the coefficient on liberalization is not affected if we control for US stock returns or for domestic economic variables. Also, the choice of estimation technique appears to have no effect. Whether we assume the presence of cross-sectional heteroscedasticity (under generalized least squares) or of heteroscedasticity and contemporaneous correlation (in the case of seemingly unrelated regressions), current account liberalization appears to have a strong positive effect on equity returns.

This is also true in every national subsample, with the exception of the United Kingdom (Table 4). Results are always statistically significant at the 10\% level. The exceptions are Germany, where we find 1\%

Table 3. Panel regression: stock market reaction to current account convertibility

\begin{tabular}{|c|c|c|c|c|c|c|}
\hline \multirow{2}{*}{$\begin{array}{l}\text { Estimation method: } \\
\text { Regression: }\end{array}$} & \multicolumn{3}{|c|}{ GLS } & \multicolumn{3}{|c|}{ SUR } \\
\hline & 1 & 2 & 3 & 4 & 5 & 6 \\
\hline Liberalize & $0.028 * * *$ & $0.023 * * *$ & $0.022 * * *$ & $0.025 * * *$ & $0.021 * * *$ & $0.019 * *$ \\
\hline$R^{U S}$ & & $\begin{array}{l}0.37^{* * *} \\
(4.6)\end{array}$ & $\begin{array}{l}0.37 * * * \\
(5.1)\end{array}$ & & $\begin{array}{l}0.37 * * * \\
(4.1)\end{array}$ & $\begin{array}{l}0.37^{* * *} \\
(4.1)\end{array}$ \\
\hline$\pi$ & & & $\begin{array}{l}-0.29 * * * \\
(1.1)\end{array}$ & & & $\begin{array}{c}-0.47^{*} \\
(1.7)\end{array}$ \\
\hline$\Delta I$ & & & $\begin{array}{c}0.01 \\
(0.3)\end{array}$ & & & $\begin{array}{c}-0.007 \\
(0.2)\end{array}$ \\
\hline$R^{2}$ & 0.029 & 0.085 & 0.085 & 0.04 & 0.085 & 0.082 \\
\hline$N$ & 444 & 444 & 444 & 444 & 444 & 444 \\
\hline
\end{tabular}

Note: $* * *, * * *$ indicate significance at the $10 \%, 5 \%$ and $1 \%$ level, respectively.

Sample period is 1950:08 to 1960:01. Countries included are Italy, Germany, France and the UK. T-statistics (in brackets) are based on heteroscedasticity-consistent standard errors and covariances. The dependent variable is the continuously compounded monthly real return of the national share price index (see Appendix B for details). Liberalize is a dummy variable for the introduction of current account convertibility, set equal to 1 from $T^{*}-5$ to $T^{*}+6$ (where $T^{*}$ is the implementation month for the introduction of currency convertibility). $R^{U S}$ is the continuously compounded real return on the US stock market index (for details of data construction, cf. Appendix B). Intercept and three country dummies included but not reported.

Table 4. Stock market reaction to current account convertibility

\begin{tabular}{|c|c|c|c|c|c|c|c|c|c|c|c|c|}
\hline \multirow[b]{2}{*}{ Regression: } & \multicolumn{3}{|c|}{ Germany } & \multicolumn{3}{|c|}{ France } & \multicolumn{3}{|c|}{ Italy } & \multicolumn{3}{|c|}{ GB } \\
\hline & 1 & 2 & 3 & 4 & 5 & 6 & 7 & 8 & 9 & 10 & 11 & 12 \\
\hline Liberalize & $\begin{array}{l}0.031 * * * \\
(3.5)\end{array}$ & $\begin{array}{l}0.028 * * \\
(2.12)\end{array}$ & $\begin{array}{c}0.026^{*} \\
(1.95)\end{array}$ & $\begin{array}{l}0.028 * \\
(1.73)\end{array}$ & $\begin{array}{l}0.028 * \\
(1.8)\end{array}$ & $\begin{array}{c}0.028^{*} \\
(1.82)\end{array}$ & $\begin{array}{l}0.031^{* *} \\
(2.4)\end{array}$ & $\begin{array}{l}0.024 * \\
(1.9)\end{array}$ & $\begin{array}{l}0.024 * \\
(1.9)\end{array}$ & $\begin{array}{c}0.02 \\
(1.43)\end{array}$ & $\begin{array}{l}0.014 \\
(1.0)\end{array}$ & $\begin{array}{c}0.01 \\
(0.8)\end{array}$ \\
\hline$R^{U S}$ & & $\begin{array}{c}0.2 \\
(1.32)\end{array}$ & $\begin{array}{c}0.22 \\
(1.49)\end{array}$ & & $\begin{array}{l}0.65^{* * * *} \\
(3.8)\end{array}$ & $\begin{array}{l}0.66^{* * *} \\
(3.8)\end{array}$ & & $\begin{array}{l}0.35^{* *} \\
(2.4)\end{array}$ & $\begin{array}{l}0.37^{* * * *} \\
(2.5)\end{array}$ & & $\begin{array}{l}0.37 * * * \\
(2.4)\end{array}$ & $\begin{array}{l}0.37 * * * \\
(2.3)\end{array}$ \\
\hline$\pi$ & & & $\begin{array}{l}-0.88^{* * * *} \\
(1.5)\end{array}$ & & & $\begin{array}{c}-0.05 \\
(0.1)\end{array}$ & & & $\begin{array}{l}0.05^{* *} \\
(0.12)\end{array}$ & & & $\begin{array}{c}-0.52 \\
(0.9)\end{array}$ \\
\hline$\Delta I$ & & & $\begin{array}{c}-0.07 \\
(0.08)\end{array}$ & & & $\begin{array}{c}0.32 \\
(1.45)\end{array}$ & & & $\begin{array}{c}0.038 \\
(0.75)\end{array}$ & & & $\begin{array}{c}-0.045 \\
(0.6)\end{array}$ \\
\hline$R^{2}$ & 0.04 & 0.047 & 0.5 & 0.017 & 0.12 & 0.12 & 0.05 & 0.09 & 0.11 & 0.004 & 0.05 & 0.04 \\
\hline$N$ & 113 & 113 & 113 & 114 & 114 & 114 & 103 & 103 & 103 & 114 & 114 & 114 \\
\hline
\end{tabular}

Note: $* * *, * * *$ indicate significance at the $10 \%, 5 \%$ and $1 \%$ level, respectively.

Sample period is 1950:08 to 1960:01. Constant included but not reported. Dependent variable is the continuously compounded monthly real return on the German stock market index. $R^{U S}$ is the continuously compounded real return on the US stock market, $\Delta I$, is the monthly rate of change of industrial production, and $\pi$ is the consumer rice inflation. Estimation technique is OLS. For data sources, cf. Appendix B. 
significance, and Britain, where the $t$-statistic drops below commonly accepted levels if we control for possible interactions with the US stock market and the influence of inflation and industrial production. In Germany, France and Italy, for every month in the event window, we find abnormal returns of $2.8 \%$ to $3 \%$ in the simplest regression set-up. This implies cumulative abnormal returns of $34 \%$ to $36 \%$. Once we control for possible movements with foreign stock markets-taking the US market as a proxy-the returns are somewhat smaller, but remain sizeable. Even if we account for the influence of other country-specific variables such as inflation and the growth of industrial output, the cumulative abnormal returns are $29 \%$ and $34 \%$. The effect in Britain was smaller, and the coefficient is not statistically significant at conventional levels.

The case that looks strikingly different is Britain-returns are positive and sizeable in the 'naive' regression specification, but no significant results emerge. Britain is different from the other EPU members in that it liberalized more gradually, with earlier steps towards greater convertibility. The most significant change came in March 1954, when the London gold market re-opened and the UK widened transferability of sterling outside the dollar area (Kaplan and Schleiminger, 1989). Arguably, therefore, the UK was less closed to outside capital in the final stage of EPU than other member countries - and it reinforces our conclusions that returns were not as high there as they were elsewhere. If this were true, the benefits of greater capital market integration must have accrued at some stage-and the change in March 1954 is the obvious point in time to examine. Table 5 gives the results. Just as in the case of other liberalizations of the current account, we find significant positive returns. The magnitude is somewhat smaller than that found for other countries in 1958/59. The effect is significant in the baseline specification, but for the alternative regressions including macroeconomic controls, the liberalization dummy is only significant at the $11 \%$ and $15 \%$ levels. Note also that the combined effect of the liberalizations in Britain in 1954 and 1959 is approximately equal to the effect observed elsewhere.

Did trade liberalizations lead to higher stock market values simply because expected rates of growth increased? The role of lowering barriers to exports and imports in Europe's spectacular post-war boom has often been emphasized. Our argument emphasizing the role of risk diversification would then have to be discarded. By controlling for macroeconomic variables in our regressions, we have already reduced the likelihood of such an objection being true. ${ }^{23}$ We test for this possibility by examining other liberalization events during the period in question. EPU proceeded by extending the list of goods for which import and export licences were no longer necessary. Gradual progress on this count was sometimes checked by individual events - such as in February 1951, when Germany suspended liberalization, or in June 1957, when France did the same (Kaplan and Schleiminger, 1989). In these crises, import controls were

Table 5. Britain's liberalization in 1954

\begin{tabular}{lccc}
\hline Estimation method: & \multicolumn{2}{c}{ OLS } \\
\cline { 2 - 4 } Regression: & 1 & 2 & 3 \\
\hline GOLDLIB & $0.027^{* *}$ & 0.024 & 0.024 \\
$R^{U S}$ & $(2.01)$ & $(1.61)$ & $(1.45)$ \\
& & 0.11 & 0.08 \\
$\pi$ & & $(0.41)$ & $(0.26)$ \\
$\Delta I$ & & $-0.81 *$ & $(0.51$ \\
$R^{2}$ & & $(1.7)$ & -0.04 \\
$N$ & 0.05 & & $(0.47)$ \\
& 54 & 0.04 & 0.01 \\
\hline
\end{tabular}

Note: $*, * *, * * *$ indicate significance at the $10 \%, 5 \%$ and $1 \%$ level, respectively.

Sample period is 1950:08 to 1954:10. T-statistics (in brackets) are based on White heteroscedasticity-consistent standard errors and covariances. The dependent variable is the continuously compounded real return of the monthly British share price index (see Appendix B for details). Other variables as in Table 4. UKLIB is set to 1 from 1953:11 to 1954:10, 0 otherwise. Constant included but not reported. 
re-instituted. We test for the effects of these interventions using the same methodology as above. If other liberalizations had effects similar to the introduction of current account convertibility, we would expect similar coefficients.

In all specifications in Table 6, the coefficient on other liberalizations is one order of magnitude smaller than for the introduction of current account liberalizations. Also, $t$-statistics are never significant. There is no direct evidence to suggest that current account liberalization was just one of a series of trade liberalizations that increased stock market values through an acceleration of growth. Our results are also robust to changes in the length of the event window used. Table 7 gives the results if we shorten the window length to eight months (Liberalize2), or three months (Liberalize3). The effect of liberalization is robust for Liberalize2; for Liberalize3, the $t$-statistic is somewhat below conventional levels. Only if we use SUR

Table 6. Panel regressions: stock market reaction to other trade liberalizations

\begin{tabular}{|c|c|c|c|c|c|c|}
\hline \multirow{2}{*}{$\begin{array}{l}\text { Estimation method: } \\
\text { Regression: }\end{array}$} & \multicolumn{3}{|c|}{ GLS } & \multicolumn{3}{|c|}{ SUR } \\
\hline & 1 & 2 & 3 & 4 & 5 & 6 \\
\hline$O L I B$ & $\begin{array}{l}0.011 \\
(1.5)\end{array}$ & $\begin{array}{l}0.0077 \\
(1.1)\end{array}$ & $\begin{array}{c}0.006 \\
(0.93)\end{array}$ & $\begin{array}{l}0.0035 \\
(0.6)\end{array}$ & $\begin{array}{l}0.003 \\
(0.4)\end{array}$ & $\begin{array}{c}0.002 \\
(0.28)\end{array}$ \\
\hline$R^{U S}$ & & $\begin{array}{l}0.4^{* *} \\
(5.4)\end{array}$ & $\begin{array}{l}0.4^{* *} \\
(5.5)\end{array}$ & & $\begin{array}{l}0.41^{* * *} \\
(4.5)^{2}\end{array}$ & $\begin{array}{l}0.41^{* * *} \\
(4.4)\end{array}$ \\
\hline$\pi$ & & & $\begin{array}{c}-0.36^{* *} \\
(1.35)\end{array}$ & & & $\begin{array}{l}-0.46^{* *} \\
(1.9)\end{array}$ \\
\hline$\Delta I$ & & & $\begin{array}{c}0.01 \\
(0.32)\end{array}$ & & & $\begin{array}{l}0.007 \\
(0.2)\end{array}$ \\
\hline$R^{2}$ & 0.009 & 0.06 & 0.07 & 0.004 & 0.06 & 0.06 \\
\hline$N$ & 444 & 444 & 444 & 444 & 444 & 444 \\
\hline
\end{tabular}

Note: $*, * *, * * *$ indicate significance at the $10 \%, 5 \%$ and $1 \%$ level, respectively.

Sample period is 1950:08 to 1960:01. T-statistics (in brackets) are based on White heteroscedasticity-consistent standard errors and covariances. The dependent variable is the continuously compounded real return of the monthly national share price index (see Appendix B for details). Variables as in Table 4, except for $O L I B$ - other trade liberalizations, ace. to Kapfan and Schleiminger (1989) (value takes three values: 1 for liberalizations -1 for suspensions of liberalizations, and 0 for all other events). Event window from $T^{*}-5$ to $T^{*}+6$. We estimate with a fixed intercept and three country dummies.

Table 7. Panel regressions: stock market reaction to current account convertibility

\begin{tabular}{|c|c|c|c|c|}
\hline \multirow{2}{*}{$\begin{array}{l}\text { Estimation method: } \\
\text { Regression: }\end{array}$} & \multicolumn{2}{|c|}{ GLS } & \multicolumn{2}{|c|}{ SUR } \\
\hline & 1 & 2 & 3 & 4 \\
\hline Liberalize2 & $\begin{array}{l}0.016^{*} \\
(3.1)\end{array}$ & & $\begin{array}{c}0.012 \\
(1.34)\end{array}$ & \\
\hline Liberalize3 & & $\begin{array}{c}0.015 \\
(1.63)\end{array}$ & & $\begin{array}{l}0.007 \\
(0.5)\end{array}$ \\
\hline$R^{U S}$ & $\begin{array}{l}0.4 * * * \\
(5.4)\end{array}$ & $\begin{array}{l}0.41 * * * \\
(5.6)\end{array}$ & $\begin{array}{l}0.39^{* * *} \\
(4.4)\end{array}$ & $\begin{array}{l}0.41^{* * *} \\
(4.4)\end{array}$ \\
\hline$\pi$ & $\begin{array}{c}-0.35^{* * *} \\
(1.4 .2)\end{array}$ & $\begin{array}{r}-0.37 \\
(1.4)\end{array}$ & $\begin{array}{l}-0.45^{* * *} \\
(1.9)\end{array}$ & $\begin{array}{c}-0.46^{*} \\
(1.9)\end{array}$ \\
\hline$\Delta I$ & $\begin{array}{c}0.01 \\
(0.03)\end{array}$ & $\begin{array}{r}0.01 \\
(1.0)\end{array}$ & $\begin{array}{l}0.006 \\
(0.2)\end{array}$ & $\begin{array}{r}0.01 \\
(0.2)\end{array}$ \\
\hline $\begin{array}{l}R^{2} \\
N\end{array}$ & $\begin{array}{l}0.07 \\
444\end{array}$ & $\begin{array}{l}0.065 \\
444\end{array}$ & $\begin{array}{l}0.07 \\
444\end{array}$ & $\begin{array}{l}0.07 \\
444\end{array}$ \\
\hline
\end{tabular}

Note: $* * *, * * *$ indicate significance at the $10 \%, 5 \%$ and $1 \%$ level, respectively.

Sample period is 1950:08 to 1960:01. T-statistics (in brackets) are based on White heteroscedasticity-consistent standard errors and covariances. The dependent variable is the continuously compounded real return of the monthly national share price index (see Appendix B for details). Liberalize2 is a dummy variable for the introduction of current account convertibility, set equal to 1 from $T^{*}-3$ to $T^{*}+4$ (where $T^{*}$ is the implementation month for the introduction of currency convertibility; Liberalize 3 is constructed analogously, but for an event window from $T^{*}-1$ to $T^{*}+1$. We estimate with a fixed intercept and three country dummies. 
(Table 8) does the $t$-statistic fall markedly below the critical threshold. This is unlikely to undermine the trustworthiness of our results, and is more likely to be the result of well-known shortcomings of the Parks estimator (Beck and Katz, 1995).

The dummy variable method has the benefit of controlling for possible changes in the regression coefficients during the event window. In contrast, estimating abnormal returns based on a forecasting equation up to the beginning of the event may suffer from specification errors (Binder, 1998). To demonstrate the robustness of our results, we also plot CARs (cumulative abnormal returns) in Figure 1.

Table 8. Panel regression: stock market reaction to capital controls

\begin{tabular}{|c|c|c|c|c|c|c|}
\hline \multirow[t]{2}{*}{ Estimation method: } & \multicolumn{3}{|c|}{ GLS } & \multicolumn{3}{|c|}{ SUR } \\
\hline & 1 & 2 & 3 & 4 & 5 & 6 \\
\hline Spread & $\begin{array}{l}-0.005^{* * *} \\
(5.6)\end{array}$ & $\begin{array}{l}-0.004 * * * \\
(4.5)\end{array}$ & $\begin{array}{l}-0.0037 * * * \\
(3.7)\end{array}$ & $\begin{array}{l}-0.006 * * * \\
(5.5)\end{array}$ & $\begin{array}{l}-0.0038 * * * \\
(4.7)\end{array}$ & $\begin{array}{l}-0.0033 * * * \\
(3.6)\end{array}$ \\
\hline$R^{w}$ & & $\begin{array}{l}0.51^{* * * *} \\
(18.3)\end{array}$ & $\begin{array}{l}0.51^{* * *} \\
(17.2)\end{array}$ & & $\begin{array}{l}0.52 * * * \\
(19.8)\end{array}$ & $\begin{array}{l}0.51^{* * * *} \\
(18.9)\end{array}$ \\
\hline$\pi$ & & & $\begin{array}{r}-0.29 \\
(1.1)\end{array}$ & & & $\begin{array}{r}-0.27 \\
(1.1)\end{array}$ \\
\hline$\Delta I$ & & & $\begin{array}{l}0.15^{* *} \\
(2.2)\end{array}$ & & & $\begin{array}{c}0.15^{*} \\
(1.94)\end{array}$ \\
\hline Int & & & $\begin{array}{c}-0.0002 \\
(0.6)\end{array}$ & & & $\begin{array}{c}-0.0003 \\
(0.8)\end{array}$ \\
\hline$R^{2}$ & 0.019 & 0.21 & 0.22 & 0.019 & 0.21 & 0.22 \\
\hline$N$ & 1470 & 1470 & 1341 & 1470 & 1470 & 1341 \\
\hline
\end{tabular}

Note: $* * *, * * *$ indicate significance at the $10 \%, 5 \%$ and $1 \%$ level, respectively.

Sample period is 1960:01 to 1998:01. Countries included are Germany, France, the UK and the USA. T- statistics (in brackets) are based on heteroscedasticity-consistent standard errors and covariances. The dependent variable is the continuously compounded monthly real return of the national share price index (see Appendix B for details). Spread is the absolute value of the difference between the national interest rate and the Euromarket rate denominated in domestic currency. $R^{w}$ is the continuously compounded real return on the MSCI World Index. Intercept and three country dummies included but not reported. For data sources, cf. Appendix B.

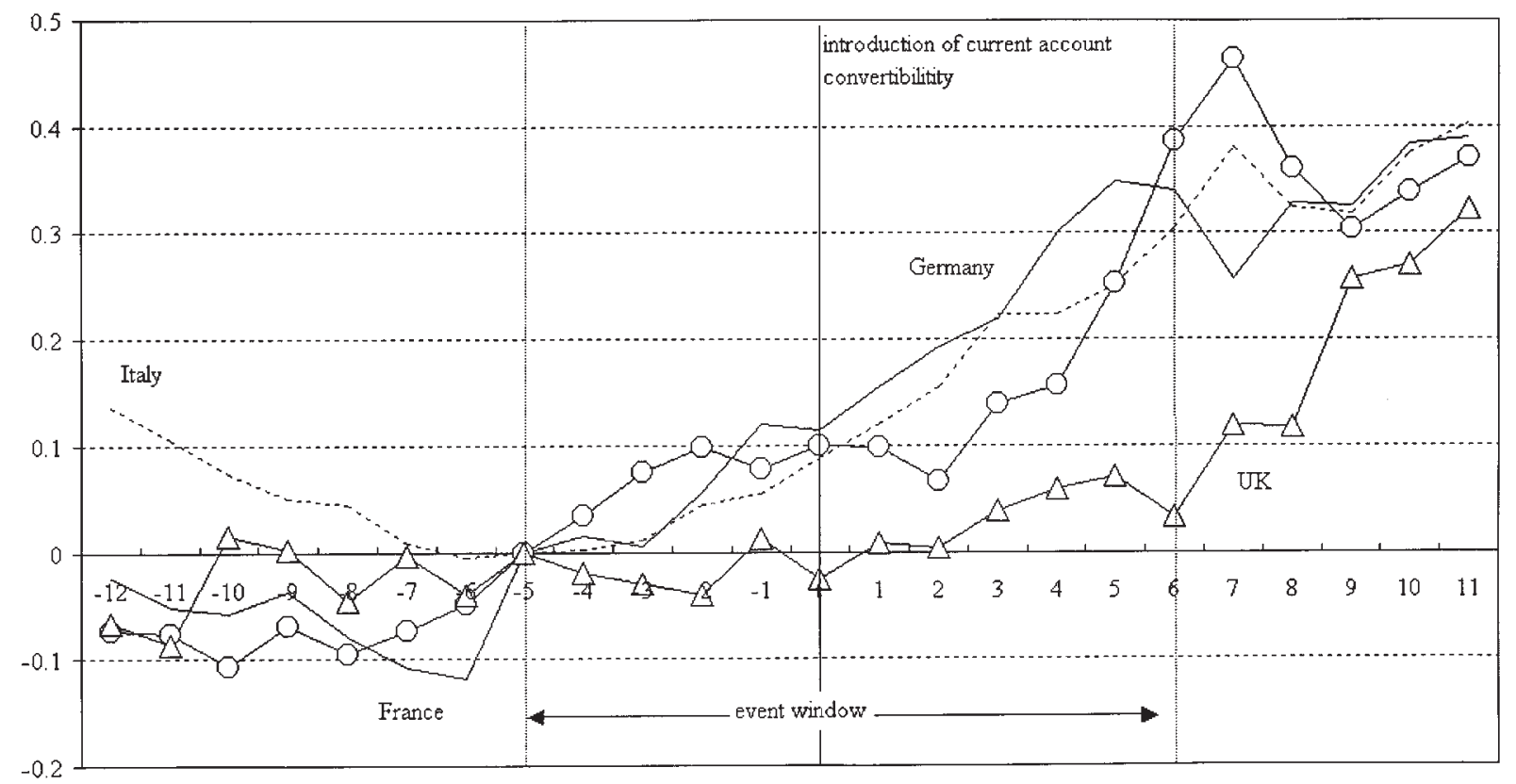

Figure 1. Cumulative abnormal returns. 
We find essentially identical results. Approximately six months prior to the introduction of full convertibility, abnormal returns begin to accumulate; within six months of current account liberalization, European stock indices rose by $15-45 \%$.

\section{THE COST OF CAPITAL CONTROLS}

Increasing capital controls in the late 1960s and early 1970s offer an additional opportunity to examine the impact of intervention. We shall first examine the effects on stock returns in general, and then turn to the most famous example - the case of Germany. The difference between domestic and Euromarket interest rates is widely accepted as a good indicator of the efficacy of capital controls (Marston, 1995). Even under relatively weak conditions for market efficiency, interest rate differentials of more than a few basis points should not persist, given that the maturity, default risk and currency risk of the instruments are almost identical. ${ }^{24}$ In contrast, most countries in our sample engineered spreads of up to 10 percentage points at their peak, and succeeded in sustaining differentials of several percentage points for extended periods. The instruments included, amongst others, taxes on capital movements, taxes to equalize interest rates (such as the US interest equalization tax), compulsory minimum reserve requirements, and prohibitions to borrow abroad (Battilossi, 2001; Bakker, 1993).

Table 9 demonstrates the effects of diminishing capital market integration on stock returns. We find a consistent negative effect of greater absolute spreads, indicating that the greater the artificial wedge between domestic and international interest rates produced by intervention, the lower the stock returns. ${ }^{25}$ The effect is sizeable. Marston (1995) calculates that the spread between onshore and offshore rates in the UK increased by $0.74 \%$ from the period $1961-71$ to $1973-79$, when capital controls were fully in force. Our estimates suggest the intervention lowered stock returns by $0.24 \%$ to $0.44 \%$ per month $(2.9 \%$ to $5.3 \%$ per year). ${ }^{26}$ Note that, since most countries in our sample chose to limit outflows, domestic interest rates were held at artificially low levels. This in itself should have helped stocks - as the negative coefficient on the domestic interest rate variable in regressions 3 and 6 demonstrates.

Nonetheless, capital controls are often imposed at a time of economic crisis-and unusually low stock market returns might well reflect deteriorating fundamentals rather than a genuine increase in the cost of

Table 9. Panel regression: stock market reaction to capital controls

\begin{tabular}{|c|c|c|c|c|}
\hline \multirow[t]{2}{*}{ Estimation method: } & \multicolumn{2}{|c|}{ GLS } & \multicolumn{2}{|c|}{ SUR } \\
\hline & 1 & 2 & 3 & 4 \\
\hline Spread + & $\begin{array}{c}-0.002 * \\
(1.68)\end{array}$ & $\begin{array}{c}-0.002 \\
(1.5)\end{array}$ & $\begin{array}{c}-0.002 * \\
(1.8)\end{array}$ & $\begin{array}{c}-0.002^{*} \\
(1.62)\end{array}$ \\
\hline$R^{w}$ & $\begin{array}{l}0.8^{* * * *} \\
(28.5)\end{array}$ & $\begin{array}{l}0.82 * * * \\
(31.3)\end{array}$ & $\begin{array}{l}0.79 * * * \\
(26.5)\end{array}$ & $\begin{array}{l}0.82^{* * * *} \\
(27.9)^{2}\end{array}$ \\
\hline$\pi$ & & $\begin{array}{c}-0.09 \\
(0.33)\end{array}$ & & $\begin{array}{c}-0.09 \\
(0.31)\end{array}$ \\
\hline$\Delta I$ & & $\begin{array}{c}0.11 \\
(1.11)\end{array}$ & & $\begin{array}{c}0.12 \\
(0.86)\end{array}$ \\
\hline $\begin{array}{l}R^{2} \\
N\end{array}$ & $\begin{array}{l}0.14 \\
374\end{array}$ & $\begin{array}{l}0.16 \\
365\end{array}$ & $\begin{array}{l}0.14 \\
374\end{array}$ & $\begin{array}{l}0.16 \\
374\end{array}$ \\
\hline
\end{tabular}

Note: $* * *, * * *$ indicate significance at the $10 \%, 5 \%$ and $1 \%$ level, respectively.

Sample period is 1960:01 to 1998:01. Countries included are Germany, France, the UK and the USA. T-statistics (in brackets) are based on heteroscedasticity-consistent standard errors and covariances. The dependent variable is the continuously compounded monthly real return of the national share price index (see Appendix B for details). Spread + is the absolute value of the difference between the national interest rate and the Euromarket rate denominated in domestic currency for months when industrial production did not decline. $R^{w}$ is the continuously compounded real return on the MSCI World Index. Intercept and three country dummies included but not reported. For data sources, cf. Appendix B. 
capital. Typically, governments resorted to capital controls when they felt unable to defend the fixed exchange rate by other means. Reserves were often running low, industrial exports had become uncompetitive, and capital was fleeing the country, possibly to profit from a devaluation that was becoming increasingly likely. The repeated British crises follow such a pattern. By limiting capital outflows, countries are effectively 'buying time' and allowing the economy to recover by keeping interest rates lower than they would otherwise have been. It is not difficult to see why, under conditions such as these, stock returns might be unusually low-and severing the link with the world capital market may not be a cause of the negative coefficient that we find in Table 9. Controlling for industrial output growth and inflation should go some way towards addressing concerns that the spreads widened during periods of unusually disappointing macroeconomic performance. We find no evidence that the coefficient on Spread becomes insignificant, even if its size drops somewhat.

To examine this issue further, we use three alternative tests. First, we examine the impact of the spread variable only for those periods with favourable economic conditions. Second, we use dividend yields as a dependent variable. Third, we focus more closely on one usual case of capital controls-Germany. If the effect documented in Table 9 is spurious because capital controls are simply indicative of economic crisis, we should expect to find insignificant or even positive coefficients during periods when overall economic performance was favourable. As a simple test, we examine the subset of months during which industrial production rose, and test for the impact of higher spreads. The results in Table 10 suggest that higher spreads had a negative effect on stock market valuations, even if industrial production rose in the same month. This is true in all specifications, and independent of the range of control variables used-except for specification 2, where the $t$-statistic is marginally below customary levels of significance. Weaking the link with the world capital market had significant costs, even in good times.

Spreads are known to widen in response to speculative pressure against a currency. If attacks by speculators are indicative of a wider economic crisis, we would also expect a negative correlation between them and equity returns. ${ }^{27}$ To reduce the danger that our results are driven by the negative consequences of foreign exchange speculation, we regress spreads on the attack variable as calculated by Eichengreen et al. (1996). The residuals of this regression provide a measure of the degree of capital market separation that is not driven by acute pressures on a currency. In Table 10, we use these residuals as an explanatory variable.

Table 10. Panel regression: stock market reaction to capital controls, net of speculative attacks

\begin{tabular}{|c|c|c|c|c|c|c|}
\hline \multirow[t]{2}{*}{ Estimation method: } & \multicolumn{3}{|c|}{ GLS } & \multicolumn{3}{|c|}{ SUR } \\
\hline & 1 & 2 & 3 & 4 & 5 & 6 \\
\hline SpreadR & $\begin{array}{l}-0.0063 * * * \\
(4.3)\end{array}$ & $\begin{array}{l}-0.0048 * * * \\
(3.6)\end{array}$ & $\begin{array}{l}-0.004 * * * \\
(3.1)\end{array}$ & $\begin{array}{l}-0.006^{* * *} \\
(4.4)\end{array}$ & $\begin{array}{l}-0.0048 * * * \\
(3.7)\end{array}$ & $\begin{array}{l}-0.004 * * \\
(3.1)\end{array}$ \\
\hline$R^{w}$ & & $\begin{array}{l}0.48^{* * *} \\
(12.8)\end{array}$ & $\begin{array}{l}0.48^{* * *} \\
(11.9)\end{array}$ & & $\begin{array}{l}0.49^{* * *} \\
(14.0)\end{array}$ & $\begin{array}{l}0.48^{* * * *} \\
(13.6)\end{array}$ \\
\hline$\pi$ & & & $\begin{array}{c}-0.18 \\
(0.6)\end{array}$ & & & $\begin{array}{c}-0.12 \\
(0.4)\end{array}$ \\
\hline$\Delta I$ & & & $\begin{array}{l}0.18 * * \\
(2.4)\end{array}$ & & & $\begin{array}{l}0.17^{*} \\
(1.9)\end{array}$ \\
\hline Int & & & $\begin{array}{c}-0.0007 \\
(1.5)\end{array}$ & & & $\begin{array}{l}0.0008 \\
(1.45)\end{array}$ \\
\hline$R^{2}$ & 0.019 & 0.22 & 0.22 & 0.008 & 0.19 & 0.19 \\
\hline$N$ & 908 & 908 & 908 & 908 & 908 & 908 \\
\hline
\end{tabular}

Note: $* * *, * * *$ indicate significance at the $10 \%, 5 \%$ and $1 \%$ level, respectively.

Sample period is 1967:01 to 1998:01. Countries included are Germany, France, the UK and the USA. T-statistics (in brackets) are based on heteroscedasticity-consistent standard errors and covariances. The dependent variable is the continuously compounded monthly real return of the national share price index (see Appendix B for details). SpreadR is the absolute value of the residuals of a GLS regression of spreads on the speculative attack variable, as defined by Eichengreen et al. (1996). The data is available at http:// haas.berkeley.edu/ arose/RecRes.htm. The start date for their variable is January 1967. $R^{w}$ is the continuously compounded real return on the MSCI World Index. Intercept and three country dummies included but not reported. For data sources, cf. Appendix B. 
The results are largely unchanged, and continue to indicate that returns fall as the wedge between domestic and international markets widens-even during non-crises. The coefficients on the spread variable are only marginally smaller than in the initial set-up, and remain significant at the 5\% level throughout.

Our second test uses dividend yields — available from the 1960s—as a dependent variable. If higher spreads simply coincided with economic downturns, we would expect dividends to fall as well. If this alternative interpretation is correct, the coefficient on the spread variable should be negative-higher spreads should coincide with lower dividend yields, as earnings collapse. If, on the other hand, the coefficient is positive, then higher spreads principally coincide with higher costs of capital.

As Table 11 demonstrates, larger spreads are systematically associated with higher dividend yields - again suggesting that the cost of capital is higher when the free flow of capital is hindered. This finding is particularly useful in reinforcing our earlier findings, as there is good reason to believe that dividend yields are more effective indicators of the cost of capital than excess returns (Bekaert and Harvey, 2000). In our baseline regressions, we used the absolute value of the spread in any given country at time $t$ as an indicator of capital market integration. The underlying assumption was that deviations from zero had symmetric implications for risk diversification, and hence, the shadow equity premium. However, it could be argued that one should expect very different implications from positive and negative spreads-whether authorities tried to engineer lower or higher domestic rates might be seen as an indicator of economic confidence, for example. Table 12 estimates the effect of spreads separately for positive and negative values, and then tests for the equality of the coefficients. The magnitudes are very similar throughout. Using the Wald $F$-test for coefficient restrictions, we find that we can never reject the null that the coefficient on PSpread is equal to - NSpread. There is therefore no reason to believe that stock markets reacted asymmetrically to different kinds of 'sand in the wheels' - the absolute value of spreads, measuring the extent to which capital markets were kept apart from the world market, determined the cost of equity finance.

The third test of the hypothesis examines the case of Germany more closely. To avoid rapid appreciation of the currency as a result of increasing doubts about the dollar, the country introduced a whole host of measures designed to avoid capital inflows (Dooley and Isard, 1980). While in force, they proved unusually effective, driving domestic rates higher than the Euromarket rate by an average of almost 3\% (Marston, 1993). The German episode is useful in that it reduces the likelihood of reverse causation. Economic

Table 11. Panel regression: dividend yields and capital controls

\begin{tabular}{|c|c|c|c|c|c|c|}
\hline \multirow[t]{2}{*}{ Estimation method: } & \multicolumn{3}{|c|}{ GLS } & \multicolumn{3}{|c|}{ SUR } \\
\hline & 1 & 2 & 3 & 4 & 5 & 6 \\
\hline Spread & $\begin{array}{l}0.24 * * * \\
(6.3)\end{array}$ & $\begin{array}{l}0.18^{* * * *} \\
(8.4)\end{array}$ & $\begin{array}{l}0.11^{* * * *} \\
(4.6)\end{array}$ & $\begin{array}{l}0.18^{* * * *} \\
(8.5)\end{array}$ & $\begin{array}{l}0.185^{* * *} \\
(11.3)\end{array}$ & $\begin{array}{l}0.099 * * * \\
(5.7)\end{array}$ \\
\hline$D Y^{U S}$ & & $\begin{array}{l}0.99^{* *} \\
(49.1)\end{array}$ & $\begin{array}{l}0.85^{* * * *} \\
(33.7)\end{array}$ & & $\begin{array}{l}0.98^{* * * *} \\
(38.2)\end{array}$ & $\begin{array}{l}0.84 * * * \\
(27.1)\end{array}$ \\
\hline$\pi$ & & & $\begin{array}{l}26.7 * * * \\
(5.2)\end{array}$ & & & $\begin{array}{l}24.5^{* * * *} \\
(4.99)\end{array}$ \\
\hline$\Delta I$ & & & $\begin{array}{l}-1.3 \\
(1.34)\end{array}$ & & & $\begin{array}{c}-1.2 \\
(0.86)\end{array}$ \\
\hline Int & & & $\begin{array}{l}0.09^{* * * *} \\
(11.3)^{2}\end{array}$ & & & $\begin{array}{l}0.1^{* * *} \\
(9.8)\end{array}$ \\
\hline$R^{2}$ & 0.22 & 0.68 & 0.67 & 0.21 & 0.68 & 0.66 \\
\hline$N$ & 421 & 421 & 369 & 421 & 369 & 369 \\
\hline
\end{tabular}

Note: $* * *, * * *$ indicate significance at the $10 \%, 5 \%$ and $1 \%$ level, respectively.

Sample period is 1960:01 to 1998:01. Countries included are Germany, France, the UK and the USA. T-statistics (in brackets) are based on heteroscedasticity-consistent standard errors and covariances. The dependent variable is the average dividend yield of shares contained in the national share price index (see Appendix B for details). Spread is the absolute value of the difference between the national interest rate and the Euromarket rate denominated in domestic currency. $D Y^{U S}$ is the dividend yield for S\&P 500. Intercept and three country dummies included but not reported. For data sources, cf. Appendix B. 
Table 12. Panel regression: stock market reaction to capital controls, positive and negative spreads estimated separately

\begin{tabular}{|c|c|c|c|c|c|c|}
\hline \multirow[t]{2}{*}{ Estimation method: } & \multicolumn{6}{|c|}{ GLS } \\
\hline & 1 & 2 & 3 & 4 & 5 & 6 \\
\hline PSpread & $\begin{array}{c}-0.006^{* * *} \\
(3.34)\end{array}$ & & $\begin{array}{l}-0.0036^{* * * *} \\
(2.4)\end{array}$ & & $\begin{array}{l}-0.0031 * * \\
(2.05)\end{array}$ & \\
\hline NSpread & & $\begin{array}{l}0.0049 \text { *** } \\
(3.3)\end{array}$ & & $\begin{array}{l}0.0044 * * * \\
(3.0)\end{array}$ & & $\begin{array}{l}0.0038^{* *} \\
(2.51)\end{array}$ \\
\hline$R^{w}$ & & & $\begin{array}{l}0.54^{* * *} \\
(13.5)\end{array}$ & $\begin{array}{l}0.37 * * \\
(4.2)\end{array}$ & $\begin{array}{l}0.53^{* *} \\
(12.6)\end{array}$ & $\begin{array}{l}0.37 * * * \\
(3.89)\end{array}$ \\
\hline$\pi$ & & & & & $\begin{array}{c}-0.096 \\
(0.3)\end{array}$ & $\begin{array}{c}-0.27 \\
(0.55)\end{array}$ \\
\hline$\Delta I$ & & & & & $\begin{array}{c}0.19^{*} \\
(1.88)\end{array}$ & $\begin{array}{l}0.17^{*} \\
(1.7)\end{array}$ \\
\hline Int & & & & & $\begin{array}{c}-0.0008 \\
(1.3)\end{array}$ & $\begin{array}{c}-0.0002 \\
(0.32)\end{array}$ \\
\hline$F$-test that $N$ Spread $=-P$ Spread & & 0.38 & & 0.27 & & 0.24 \\
\hline$R^{2}$ & 0.034 & 0.018 & 0.25 & 0.16 & 0.25 & 0.16 \\
\hline$N$ & 636 & 320 & 636 & 320 & 636 & 320 \\
\hline
\end{tabular}

Note: $* * *, * * *$ indicate significance at the $10 \%, 5 \%$ and $1 \%$ level, respectively.

Sample period is 1963:01 to 1990:12. Countries included are Germany, France, the UK and the USA. T-statistics (in brackets) are based on heteroscedasticity-consistent standard errors and covariances. The dependent variable is the continuously compounded monthly real return of the national share price index (see Appendix B for details). PSpread is the value of Spread if Spread is larger than or equal to zero. Nspread is equal to the value of Spread if Spread is smaller than zero. $R^{w}$ is the continuously compounded real return on the MSCI World Index. Intercept and three country dummies included but not reported. For data sources. Continuously compounded monthly real return of cf. Appendix B.

fundamentals were strong-as Giersch et al. (1992) observe, the boom after the slight recession in 1966/67 was notable for being unusually powerful and sustained. Investors the world over were trying to put money into Germany, and interest rates were raised to higher levels than would have prevailed under full capital mobility. The only fear that motivated the German authorities was one of massive capital inflows (Bakker, 1993). ${ }^{28}$

The two main policy instruments used by the Bundesbank were the Bardepot (cash deposit) and the Mindestreserve (minimum reserve). The Bardepot required banks to deposit $40 \%$ of their liabilities incurred vis-à-vis non-residents with the Bundesbank (from March 1972). This was raised to $50 \%$ by July 1972 , before being reduced to $20 \%$ in February 1974. The Bardepot provision was finally abolished in September 1974. The minimum reserve requirement was a special reserve ratio on the growth of banks' liabilities to non-residents. Table 13 repeats our earlier analysis for Germany, using Mindestreserve and Bardepot as explanatory variables. While the coefficient on minimum reserve requirements is consistently significant and negative, Bardepot only has a significant effect at customary levels when we do not control for co-movement with foreign markets or domestic conditions. This suggests that the former was more effective in controlling capital flows. ${ }^{29}$ The effect is not small-the estimated coefficients suggest that, at its peak July 1972 to January 1974, the combined effects of the Mindestreserve and the Bardepot reduced returns by $1.4 \%$ to $2.3 \%$ real per month. To further examine the impact of capital controls, we use two alternative measures. First, we employ the dummy technique applied by Dooley and Isard (1980), who construct a variable rising in five discrete steps from 0 to 5 to measure the stringency of capital controls. Second, we use the difference between domestic and Euromarket interest rates as a proxy for the effectiveness of capital controls.

Table 14 gives the results. Dooley's and Isard's stepwise measure shows a clear negative impact on stock returns. At the height of intervention, it shaved an average of up to $2.5 \%$ off equity returns. Note that the impact is stable across specifications, including those that include the US market return and German industrial production. The only exception is when we add inflation directly, which is highly collinear with the intervention variables-concern about the need to fight inflationary tendencies motivated the intervention in the first place. ${ }^{30}$ Note that the intervention variable is once again estimated with small 
Table 13. Stock market reaction to restrictions of capital flows-Germany

\begin{tabular}{|c|c|c|c|c|c|c|}
\hline & 1 & 2 & 3 & 4 & 5 & 6 \\
\hline Bardepot & $\begin{array}{l}-0.000395^{* *} \\
(2.1)\end{array}$ & $\begin{array}{c}-0.0003^{*} \\
(1.65)\end{array}$ & $\begin{array}{c}-0.0002 \\
(1.14)\end{array}$ & & & \\
\hline Mindestreserve & & & & $\begin{array}{l}-0.00035^{* *} \\
(2.5)\end{array}$ & $\begin{array}{l}-0.00029 * * \\
(2.1)\end{array}$ & $\begin{array}{c}-0.00023^{*} \\
(1.64)\end{array}$ \\
\hline$R^{U S}$ & & $\begin{array}{l}0.32 * * * \\
(9.5)\end{array}$ & $\begin{array}{l}0.32 * * * \\
(6.2)\end{array}$ & & $\begin{array}{l}0.31^{* * *} \\
(6.5)\end{array}$ & $\begin{array}{l}0.32 * * * \\
(6.2)\end{array}$ \\
\hline$\pi$ & & & $\begin{array}{l}-0.71 * * * \\
(2.1)\end{array}$ & & & $\begin{array}{l}-0.68 * * * \\
(2.0)\end{array}$ \\
\hline$\Delta I$ & & & $\begin{array}{r}-0.03 \\
(0.5)\end{array}$ & & & $\begin{array}{c}-0.032 \\
(0.5)\end{array}$ \\
\hline$R^{2}$ & 0.0075 & 0.07 & 0.09 & 0.011 & 0.08 & 0.09 \\
\hline$N$ & 591 & 591 & 591 & 591 & 591 & 591 \\
\hline
\end{tabular}

Note: $* * *, * * *$ indicate significance at the $10 \%, 5 \%$ and $1 \%$ level, respectively.

Sample period is 1950:08 to 1999:09. Dependent variable is the continuously compounded monthly real return on the German stock market index. Bardepot is the percentage of liabilities incurred with non-residents that banks have to deposit with the Bundesbank; Mindestreserve is the percentage of the special reserve ration on the growth of liabilities with non-residents. Estimation method is OLS.

Table 14. Stock market reaction to restrictions of capital flows

\begin{tabular}{|c|c|c|c|c|c|c|c|c|c|c|}
\hline & 1 & 2 & 3 & 4 & 5 & 6 & 7 & 8 & 9 & 10 \\
\hline Step & $\begin{array}{l}-0.005^{* *} \\
(2.4)\end{array}$ & $\begin{array}{c}-0.004 * \\
(1.9)\end{array}$ & $\begin{array}{l}-0.004 * \\
(1.9)\end{array}$ & $\begin{array}{l}-0.0027 \\
(1.4)\end{array}$ & $\begin{array}{l}-0.004^{* *} \\
(1.9)\end{array}$ & & & & & \\
\hline Spread & & & & & & $\begin{array}{l}-0.0038 * * \\
(2.5)\end{array}$ & $\begin{array}{l}-0.0034 * * \\
(2.3)\end{array}$ & $\begin{array}{l}-0.003 * * \\
(2.3)\end{array}$ & $\begin{array}{l}-0.0029 * \\
(1.88)\end{array}$ & $\begin{array}{c}-0.003^{*} \\
(2.1)\end{array}$ \\
\hline$R^{U S}$ & & $\begin{array}{l}0.31^{\text {*** }} \\
(6.5)\end{array}$ & $\begin{array}{l}0.32 * * * \\
(6.5)\end{array}$ & $\begin{array}{l}0.32 * * \\
(6.2)\end{array}$ & $\begin{array}{l}0.32 * * * \\
(6.3)\end{array}$ & & $\begin{array}{l}0.32^{* * *} \\
(6.3)\end{array}$ & $\begin{array}{l}0.32 * * * \\
(0.05)\end{array}$ & $\begin{array}{l}0.33 * * * \\
(6.0)\end{array}$ & $\begin{array}{l}0.33^{* * *} \\
(6.2)\end{array}$ \\
\hline$\Delta I$ & & & $\begin{array}{r}0.041 \\
(0.69)\end{array}$ & & $\begin{array}{c}-0.04 \\
(0.68)\end{array}$ & & & $\begin{array}{l}0.19^{* *} \\
(1.99)\end{array}$ & $\begin{array}{l}0.21^{*} \\
(2.0)\end{array}$ & $\begin{array}{l}0.21^{* *} \\
(2.0)\end{array}$ \\
\hline$\pi$ & & & & $\begin{array}{c}-0.69^{* * *} \\
(2.1)\end{array}$ & & & & & $\begin{array}{c}-0.3 \\
(0.6)\end{array}$ & \\
\hline$\pi(-1)$ & & & & & $\begin{array}{l}0.12 \\
(0.4)\end{array}$ & & & & & $\begin{array}{c}0.08 \\
(0.18)\end{array}$ \\
\hline$R^{2}$ & 0.0098 & 0.076 & 0.077 & 0.09 & 0.08 & 0.015 & 0.1 & 0.11 & 0.12 & 0.12 \\
\hline$N$ & 587 & 587 & 587 & 587 & 587 & 419 & 419 & 419 & 419 & 419 \\
\hline
\end{tabular}

Note: $* * *, * * *$ indicate significance at the $10 \%, 5 \%$ and $1 \%$ level, respectively.

Sample period is 1950:08 to 1999:09 for regressions 1 to 5, 1963:01 to 1998:01 for regressions 6 to 10. Constant included but not reported. Dependent variable is the continuously compounded monthly real return on the German stock market index. Step is the index of capital account restrictions constructed by Dooley and Isard (1980). Spread is the absolute value of the difference between domestic and the Eurodeutschmark 3-month interest rate. $R^{U S}$ is the continuously compounded real return on the US stock market, $\Delta I$ is the monthly rate of change of industrial production, and $\pi$ is the consumer price inflation. Estimation technique is OLS. For data sources, cf. Appendix B.

standard errors and the predicted sign if we include lagged inflation. A similar picture emerges when we use the spread between offshore and onshore rates as an indicator of capital flow restrictions. The spread variable is constructed as the difference between three-month domestic interest rates and the three-month Euromarket rate. In April 1970, at the time when the minimum reserve requirement was introduced, the domestic three-month rate was a mere $11 \mathrm{bp}$ higher than the offshore rate. Between April 1970 and September 1974, when the last provisions were abolished, it averaged 264 bp. For every increase in the spread by $100 \mathrm{bp}$, we estimate a reduction in monthly equity returns of $0.3 \%$. For the period as a whole, the cumulative impact of capital controls was $36.4 \%$ to $46.2 \%$. The German case, combined with the evidence 
on dividend yields and from the subsample of spreads coinciding with output growth therefore strongly suggests that reverse causation was not at work.

Is the result specific to our measure of capital market integration? We use spreads because there are good theoretical reasons to accept them as a measure of deviations from full capital market integration, and because they are available on a monthly basis for much of the period under consideration. An alternative indicator that has gained wide currency recently is based on a more finely calibrated indicator based on assessments in the IMF's Annual Report on Exchange Restrictions (Quinn, 1997; Quinn and Inclan, 1997). The Quinn index has the disadvantage of only being available on an annual basis. Nonetheless, if our argument concerning the consequences of capital market liberalization is correct, we should expect to find similar effects.

Table 15 presents the results for re-estimating the analysis in Table 11, using the Quinn index as an explanatory variable. ${ }^{31}$ Higher scores indicate a more liberalized capital account, on a scale from 0 to 4. Greater capital market integration should lower the dividend yield-and this is exactly what Table 15 demonstrates. Going from a fully closed (Quinn score $=0)$ to a fully liberalized capital account would, all else being equal, reduce dividend yields by between $1.32 \%$ and $2.44 \%$ - a very considerable reduction. ${ }^{32}$

Did weaking the link with the world capital market have any real effects? We already controlled for any possible interaction between lower output growth and stock returns in our earlier regressions. Table 16 examines this issue further, using the growth of ppp-adjusted per capita income over seven separate five-year periods as a dependent variable. We use the same data set as Wyplosz (2000), who argues that capital controls and financial repression may have had positive effects on growth. We add the spread variable as an indicator of the effectiveness of capital controls to Wyplosz's set-up. The correlation coefficient between the spread variable and the capital control dummy is a mere 0.46 in our sample. This strongly suggests that simply using qualitative, dichotomous variables fails to capture sufficiently the considerable variation in the effectiveness of implementation. In the case of Germany, for example, the Wyplosz dummy suggests that capital controls in the 1960s were just as stringent as they were in the early $1970 \mathrm{~s}$ - while average spreads were around $0.4 \%$ in the first period, and closer to $2.4 \%$ in the early $1970 \mathrm{~s}$.

Since spreads are not available for all countries in the data set, we first need to demonstrate that our restricted sample shows similar behaviour to the one Wyplosz found. Regression 1 shows a positive, significant and moderately large coefficient on capital controls-just as Wyplosz argued. The insignificant

Table 15. Panel regression: dividend yields and capital controls

\begin{tabular}{|c|c|c|c|c|c|c|}
\hline \multirow[t]{2}{*}{ Estimation method: } & \multicolumn{3}{|c|}{ GLS } & \multicolumn{3}{|c|}{ SUR } \\
\hline & 1 & 2 & 3 & 4 & 5 & 6 \\
\hline Quinn & $\begin{array}{c}-0.33^{*} \\
(2.04)\end{array}$ & $\begin{array}{l}-0.37 * * * \\
(2.8)\end{array}$ & $\begin{array}{l}-0.61^{*} \\
(2.4)\end{array}$ & $\begin{array}{l}-0.47 * * * \\
(3.7)\end{array}$ & $\begin{array}{c}-0.5^{* * *} \\
(4.5)\end{array}$ & $\begin{array}{l}-0.58^{* *} \\
(2.1)\end{array}$ \\
\hline$D Y^{U S}$ & & $\begin{array}{l}0.64^{* * *} \\
(4.9)\end{array}$ & $\begin{array}{l}0.8^{* * * *} \\
(7.4)\end{array}$ & & $\begin{array}{l}0.58^{* * *} \\
(6.2)\end{array}$ & $\begin{array}{l}0.82^{* * *} \\
(5.4)\end{array}$ \\
\hline$\pi$ & & $\begin{array}{c}3.4 \\
(0.9)\end{array}$ & $\begin{array}{l}4.3 \\
(0.86)\end{array}$ & & $\begin{array}{l}5.33^{* * * *} \\
(3.1)\end{array}$ & $\begin{array}{c}5.8^{*} \\
(1.65)\end{array}$ \\
\hline$\Delta I$ & & & $\begin{array}{c}-0.1 \\
(1.1)\end{array}$ & & & $\begin{array}{c}-0.08 \\
(1.2)\end{array}$ \\
\hline Int & & & $\begin{array}{l}0.046 \\
(0.8)\end{array}$ & & & $\begin{array}{c}0.02 \\
(0.62)\end{array}$ \\
\hline$R^{2}$ & 0.03 & 0.14 & 0.28 & 0.02 & 0.23 & 0.3 \\
\hline$N$ & 156 & 153 & 87 & 156 & 153 & 87 \\
\hline
\end{tabular}

Note: $*, * *, * * *$ indicate significance at the $10 \%, 5 \%$ and $1 \%$ level, respectively.

Sample period is 1950 to 1989. Countries included are Germany, France, Italy and the UK. T-statistics (in brackets) are based on heteroscedasticity-consistent standard errors and covariances. The dependent variable is the average dividend yield of shares contained in the national share price index (see Appendix B for details). Quinn is the value of the capital account liberalization index as calculated by Quinn (1997) DYUS is the dividend yield for the S\&P 500 . 
Table 16. Panel regression: GDP growth 1960-95 and capital controls

\begin{tabular}{|c|c|c|c|c|c|c|}
\hline \multirow{2}{*}{$\begin{array}{l}\text { Estimation method: } \\
\text { Regression: }\end{array}$} & \multicolumn{3}{|c|}{ Common intercept } & \multicolumn{3}{|c|}{ Fixed effects } \\
\hline & 1 & 2 & 3 & 4 & 5 & 6 \\
\hline $\begin{array}{l}\text { Initial GDP } \\
\text { p.c. }\end{array}$ & $\begin{array}{l}-0.033^{* * * *} \\
(3.7)\end{array}$ & $\begin{array}{l}-0.03 * * \\
(3.7)\end{array}$ & $\begin{array}{c}-0.03^{*} \\
(1.7)\end{array}$ & $\begin{array}{c}-0.045 \\
(1.58)\end{array}$ & $\begin{array}{c}-0.03 * \\
(1.7)\end{array}$ & $\begin{array}{l}-0.14 * * * \\
(4.3)\end{array}$ \\
\hline Spread & & $\begin{array}{l}-0.004 * * * \\
(2.9)\end{array}$ & $\begin{array}{l}-0.003 * \\
(1.7)\end{array}$ & & $\begin{array}{l}-0.005^{* * *} \\
(3.9)\end{array}$ & $\begin{array}{l}-0.002 \\
(1.5)\end{array}$ \\
\hline $\begin{array}{l}\text { Capital } \\
\text { controls }\end{array}$ & $\begin{array}{l}0.007^{*} \\
(1.7)\end{array}$ & & $\begin{array}{c}-0.006 \\
(1.3)\end{array}$ & $\begin{array}{c}-0.5 \\
(0.5)\end{array}$ & & $\begin{array}{l}-0.007 * * \\
(2.06)\end{array}$ \\
\hline $\begin{array}{l}\text { Credit } \\
\text { restraints }\end{array}$ & $\begin{array}{l}0.009 \\
(1.6)\end{array}$ & $\begin{array}{c}0.004 \\
(0.99)\end{array}$ & $\begin{array}{l}0.002 \\
(0.3)\end{array}$ & $\begin{array}{l}0.006 \\
(0.77)\end{array}$ & $\begin{array}{l}0.007 \\
(1.3)\end{array}$ & $\begin{array}{l}0.0007 \\
(0.16)\end{array}$ \\
\hline Inflation & $\begin{array}{l}-0.003^{* * *} \\
(3.3)\end{array}$ & $\begin{array}{l}-0.001 * * \\
(2.4)\end{array}$ & $\begin{array}{l}-0.001 * * * \\
(3.1)\end{array}$ & $\begin{array}{l}-0.002 * * * \\
(3.1)\end{array}$ & $\begin{array}{l}-0.002 * * * \\
(5.1)\end{array}$ & $\begin{array}{l}-0.002^{* * * *} \\
(4.2)\end{array}$ \\
\hline Openness & $\begin{array}{c}-0.004 \\
(0.5)\end{array}$ & $\begin{array}{c}-0.004 \\
(0.37)\end{array}$ & $\begin{array}{l}0.002 \\
(0.2)\end{array}$ & $\begin{array}{c}-0.02 \\
(0.2)\end{array}$ & $\begin{array}{c}-0.1 \\
(1.6)\end{array}$ & $\begin{array}{c}-0.03 \\
(0.6)\end{array}$ \\
\hline $\begin{array}{l}\text { Size of } \\
\text { government }\end{array}$ & $\begin{array}{l}0.015^{*} \\
(1.8)\end{array}$ & $\begin{array}{c}0.01 \\
(1.5)\end{array}$ & $\begin{array}{c}0.04 \\
(0.4)\end{array}$ & $\begin{array}{c}0.02 \\
(0.97)\end{array}$ & $\begin{array}{c}0.02 \\
(1.1)\end{array}$ & $\begin{array}{l}-0.07 * * * \\
(3.7)\end{array}$ \\
\hline $\begin{array}{l}\text { Higher } \\
\text { education }\end{array}$ & $\begin{array}{c}-0.04 \\
(1.1)\end{array}$ & $\begin{array}{r}-0.05 \\
(1.4)\end{array}$ & $\begin{array}{c}-0.01 \\
(0.24)\end{array}$ & $\begin{array}{r}-0.13 \\
(1.5)\end{array}$ & $\begin{array}{l}-0.16^{* * * *} \\
(4.3)\end{array}$ & $\begin{array}{l}0.13^{* *} \\
(2.01)\end{array}$ \\
\hline Fertility & $\begin{array}{l}0.0008 \\
(0.07)\end{array}$ & $\begin{array}{l}-0.001 \\
(0.1)\end{array}$ & $\begin{array}{c}0.04 \\
(1.3)\end{array}$ & $\begin{array}{l}-0.048^{* *} \\
(2.3)\end{array}$ & $\begin{array}{l}-0.05^{* * * *} \\
(2.98)\end{array}$ & $\begin{array}{l}-0.07^{* *} \\
(3.3)\end{array}$ \\
\hline$R^{2}$ & 0.62 & 0.64 & 0.84 & 0.72 & 0.73 & 0.95 \\
\hline$N$ & 32 & 32 & 32 & 32 & 32 & 32 \\
\hline
\end{tabular}

Note: $* * *, * * *$ indicate_ significance at the $10 \%, 5 \%$ and $1 \%$ level, respectively.

Sample period is 1960-95, five-year subperiods used $(1960-64,1965-69,1970-74,1975-79,1980-84,1985-89$, I990-95). Estimation method is GLS throughout. Countries included are Belgium, the Netherlands, Switzerland, Denmark, Germany, France and the UK. $T$-statistics (in brackets) are based on heteroscedasticity-consistent standard errors and covariances. The dependent variable is average growth of ppp-adjusted GDP per capita. All variables except spread as in Wyplosz (1999). Period dummies included in regressions 3 and 6.

result in equation 4 is in line with other results by Wyplosz. We are therefore not biasing our results by moving to a somewhat smaller data set. If the spread variable is large and statistically significant (or if the capital controls variable now becomes insignificant or even negative), we have also found further support for the argument that slowing cross-border capital flows is; harmful in its own right. ${ }^{33}$

The effect of the spread variable is consistently negative, and remains significant in all specifications except 6 , where it is marginally below conventional significance levels. The effect is also large. The German controls in the early 1970 , for example, added $4.3 \%$ to the spread variable compared to the period of mild controls thereafter, and lasted for 18 months (Marston, 1995). According to our estimates, they reduced growth by $1.3 \%$ to $2.6 \%$ cumulatively, in addition to the negative effect that they had through higher interest rates. In equations 3 and 6 , where we have combined the spread variable and the capital controls variable, we find that the dummy indicator used by Wyplosz actually becomes negative- even significantly so in the case of equation 6. If a commonly accepted measure of capital market integration such as the spread of offshore versus onshore instruments is used, there is a clear and unambiguous negative effect of capital controls on growth. ${ }^{34}$

In countries such as Germany, where capital controls kept domestic interest rates artificially high, the cost of equity increased even further by a higher equity premium. Where rates were kept lower, however, an abolition of controls would have had a mixed impact. Note, however, that a substantial literature argues that capital controls are a negative signal, and that the 'irreversibility' of inflows makes them less likely under a control regime (Bartolini and Drazen, 1997a,b). Interest rates therefore need not necessarily rise with the abolition of controls on outflows. However, if they do, the advantages of a lower equity premium would be reduced by higher interest rates. Would the first effect have been sufficient to outweigh the latter? 
If expected returns before and after liberalization are:

$$
\begin{aligned}
& E\left(R_{i}^{f, p r e}\right)+T \sigma_{i}^{2} \\
& E\left(R_{i}^{\text {post }}\right)=R_{w}^{f}+T \rho_{i, w} \sigma_{i} \sigma_{w}
\end{aligned}
$$

where $R_{w}^{f}$ is the risk-free rate in the world, and $R_{i}^{f, p r e}$ the pre-liberalization risk-free rate, $T$ is the equity premium, $\sigma$ is the variance of returns, and $\rho_{i, w}$ is the correlation of returns in country $i$ with the returns in the world, we will observe positive returns during liberalization if:

$$
E\left(R_{i}^{\text {pre }}\right)>E\left(R_{i}^{\text {post }}\right) \Rightarrow T \sigma_{i}\left[\sigma_{i}-\rho_{i, w} \sigma_{w}\right]>R_{w}^{f}-R_{i}^{f, p r e}
$$

If risk-free rates rose, any given increase in equity values suggests an even greater reduction in the equity premium. Stulz (1999) calculates that an increase in equity values by $30 \%$ suggests, under plausible assumptions, a fall in the cost of equity by $3.5 \%$. For the $23-34 \%$ change that we found following the abolition of currency controls, this implies a reduction in the net cost of capital by $2.8 \%$ to $3.8 \%$. Note, however, that this is before any further benefits from revoking capital controls. Regressing interest rates on the Quin index with country-specific intercepts suggests that, by going from a fully closed to a fully open capital account, countries would have had to accept interest rates that are $16 \%$ higher. ${ }^{35}$ Therefore, for a wide range of leverage ratios, the weighted average cost of capital should fall-even if access to capital was not rationed under the controls regime, which in practice it almost always was (Bakker, 1993; Wyplosz, 1999). ${ }^{36}$ The alternative approach to examining the net change in the cost of capital is to compare dividend yields (Bekaert and Harvey, 2000; Stulz, 1999). Here, we find net changes of $-1.3 \%$ to $-2.4 \%$ which already take account of any possible impact of potentially higher risk-free rates.

\section{CONCLUSIONS}

There are good theoretical reasons to believe capital and current account convertibility should be economically beneficial. However, until recently, empirical evidence to support such a view has been scarce. It is only as a result of studies by Quinn (1997), Arteta et al. (2001) and Edwards (2001) that more evidence in favour of a clear link between liberalization and growth has begun to accumulate. This paper attempts to contribute to the literature by examining the impact of liberalizations on the cost of capital in Western Europe, 1950-1999, and to document the channel through which liberalization had benign effects.

Along with other authors (Edwards, 2001), we find that the inability of earlier studies to find a significant effect of capital controls on most economic performance variables was caused by the use of simple dichotomous variables as indicators for capital controls. Second, earlier studies have largely ignored the cost of capital, instead focusing on other variables that are possibly only affected indirectly. We resolve these issues by examining two indicators of the cost of capital-dividend yields and excess returns, and by using a widely accepted indicator of the extent to which controls 'bite'- the differential between on- and offshore interest rates. We also document the value of this indicator for the effectiveness of capital controls by showing that the Quin index of capital account liberalization yields broadly similar results.

There is strong evidence to suggest that controls raised the cost of equity finance in post-war Europe significantly. We conduct a number of tests to rule out alternative causes, such as the benign effects of trade liberalization in the case of the end of EPU, and reverse causation in the case of spreads. Two historical episodes support this conclusion-the late 1950s when most European countries switched to currency convertibility, and the 1960s and 1970s, when many countries resorted to capital controls. This is important for two reasons. First, it suggests that many of the benefits of international diversification are de facto already achieved once currencies become convertible. Overcoming direct capital controls through over- and under-invoicing becomes possible, and the sizeable gains in local market indices strongly suggest that integration with the world stock market increases markedly as a result. Second, our results also cast light on the historical debate about the costs and benefits of the European Payments Union (Eichengreen, 1993). The EPU was meant to last for two years, and existed for almost nine. More than 14 years passed between 
the end of the war and the return to currency convertibility. As Eichengreen has argued, the possibility of negative consequences used to be almost completely neglected. However, even the more critical recent account of the EPU has found few drawbacks. ${ }^{37}$ By delaying the introduction of full convertibility for a number of years, EPU also had negative consequences - the benefit of a lower cost of capital arrived later than it would have done had it not been for the multilateral netting arrangement.

The introduction of capital controls by a number of European countries in the final days of the Bretton Woods System also offers a natural experiment in the consequences of erecting barriers to the free flow of capital across borders. Our results show that, where such measures succeed, there are significant negative consequences for the cost of capital. This is true independent of the underlying economic performance and of the direction in which capital is prevented from flowing - the effects in the German case, where inflows were prevented, were as harmful as they were in the UK, France and the USA, where outflows were controlled.

Also, the fact that controls remained in place for extended periods, such as in France and the UK, may have done substantial harm-especially during periods when the case for controls was doubtful. France, as Sicsic and Wyplosz (1996) noted, 'displays a mostly unexciting story' in terms of the current account, noting that it never experienced serious external imbalances after 1967. The fact that successive governments nonetheless maintained controls until the early 1990s strongly suggests policy failure. Changes in dividend yields during liberalizations also demonstrate that the claimed benefits of lower interest rates were not sufficient to offset the disadvantages of reduced risk-sharing. Model calculations strongly suggest that the positive effects from capital and current account liberalizations were large enough to lower the net cost of capital, even if higher governments had previously kept interest rates artificially low. The harm caused by capital controls cannot be assessed when the focus is on short-run phenomena such as turmoil in the currency market. Instead, the long-run impact on key economic variables such as the cost of equity needs to be assessed. These can be substantial, as the results presented in this article demonstrate.

\section{ACKNOWLEDGEMENTS}

Financial support by CREI, the Leverhulme Trust, and a Ramon y Cajal Fellowship by the Spanish Education Ministry (MCYT) is gratefully acknowledged. Seminar audiences at UPF Barcelona, Toulouse, Brisbane, Delaware and Palma de Mallorca made numerous helpful suggestions. Nick Dimsdale offered some great ideas, and Luigi Zingales's comments helped in improving the final manuscript. All remaining errors are my responsibility.

\section{APPENDIX A}

Did liberalization cause higher volatility of equity returns? We use GARCH models to address this question (Campbell et al., 1997). This involves the joint estimation of two equations - a mean equation and a variance equation:

$$
\begin{aligned}
& y_{t}=x_{t} \gamma+\varepsilon_{t} \\
& \sigma^{2}=\omega+\alpha \varepsilon_{t-1}^{2}+\beta \sigma_{t-1}^{2}
\end{aligned}
$$

The first equation relates the returns on an asset $y$ to a set of explanatory variables $x$. The second equation fits a model to the forecast (conditional) variance of asset returns. $\omega, \alpha, \gamma$ and $\beta$ are parameters, $\sigma^{2}$ is the variance, and $\varepsilon$ the error in the returns equation. Predictions of future volatility in this model are based on the long-term average value $\omega$, the size of the unpredicted return in the last period, as well as the conditional volatility in the last period. The adjustment parameter $\alpha$ measures the speed with which the conditional variance of the inflation forecast changes as a result of an unexpected change in asset returns, and $\beta$ measures the extent to which a shock to conditional volatility persists. 
We use industrial production, US returns and inflation as explanatory variables in the mean equation. In the variance equation, we use the dummy variable for current account liberalization as a regressor. There is no evidence that the high returns immediately before current account liberalization and afterwards were bought at the cost of higher volatility. While there is evidence of GARCH in all countries except the UK, the coefficient on Liberalize is never significant, and in half of all cases, estimated with the wrong sign (Table A.1).

Table A.1. GARCH models: stock market volatility and current account convertibility

\begin{tabular}{lcccc}
\hline & Germany & France & Italy & UK \\
\cline { 2 - 5 } Regression: & 1 & 2 & 3 & 4 \\
\hline Liberalize & 0.0004 & 0.00017 & -0.000134 & -0.0005 \\
& $(0.4)$ & $(0.23)$ & $(0.42)$ & $(1.3)$ \\
$\alpha$ & $0.3^{* * *}$ & $0.24^{* * *}$ & $0.15^{* * *}$ & 0.13 \\
$\beta$ & $(6.4)$ & $(3.3)$ & $(3.3)$ & 0.4 \\
& $0.4^{* * *}$ & $0.52^{* * *}$ & $0.71 * * *$ & $(1.2)$ \\
$R^{2}$ & $(3.9)$ & $(3.5)$ & $(7.9)$ & 0.26 \\
$N$ & 0.08 & 0.11 & 587 & 587 \\
\hline
\end{tabular}

Note: ***,*** indicate significance at the $10 \%, 5 \%$ and $1 \%$ level, respectively.

Sample period is 1950:08 to 1999:09. Z-statistics in brackets. In the return equations (not reported), the dependent variable is the continuously compounded monthly real return of the national share price index (see Appendix A for details). Estimation is by maximum likelihood.

\section{APPENDIX B: SOURCES}

\section{Nominal stock price indices}

France: International Financial Statistics, collected by hand before January 1957, IFS-CD ROM thereafter.

Italy: International Financial Statistics, collected by hand before January 1957, IFS-CD ROM thereafter.

Germany: Gielen (1994), pp. 181ff, column A.

UK: International Financial Statistics, collected by hand before December 1957, IFS-CD ROM thereafter.

USA: $\quad$ Standard and Poor's Long Term Security Price Index Record (NBER Macrohistory Database Series 11025) until January 1957, and from IFS-CD ROM thereafter.

World: MSCI World Index for 18 countries (dollar basis), provided by Global Financial Data (_CIWL_UD.csv).

\section{CPI indices}

France: International Financial Statistics, collected by hand before January 1960, IFS-CD ROM thereafter.

Italy: International Financial Statistics, collected by hand before January 1960, IFS-CD ROM thereafter.

Germany: Gielen (1994), pp. 181ff, column I.

UK: International Financial Statistics, collected by hand before December 1960, IFS-CD ROM thereafter.

USA: $\quad$ US CPI index, provided by Global Financial Data (CPUSAM.csv).

\section{Industrial production}

France: International Financial Statistics, collected by hand before January 1957, IFS-CD ROM thereafter. 
Italy: International Financial Statistics, collected by hand before January 1957, IFS-CD ROM thereafter.

Germany: International Financial Statistics, collected by hand before December 1957, IFS-CD ROM thereafter.

UK: International Financial Statistics, collected by hand before December 1957, IFS-CD ROM thereafter.

USA: International Financial Statistics, collected by hand before January 1957, IFS-CD ROM thereafter.

\section{Domestic interest rates}

France: 3 month Paris interbank offer rate (Pibor), from OECD Main Economic Indicators.

Italy: $\quad 3$ month interbank rate, from OECD Main Economic Indicators.

Germany: 3 month Frankfurt interbank offer rate (Fibor), from OECD Main Economic Indicators.

UK: $\quad$ yield on treasury bills, from OECD Statistical Compendium (series 26M3).

USA: $\quad$ yield on treasury bills, 3 months, from OECD Statistical Compendium

\section{Offshore rates}

France: 3 month FF deposit rate in London, from OECD Statistical Compendium (series 00EA6). Germany: 3 month DM deposit rate in London, from OECD Statistical Compendium (series 00EA4). UK: $\quad 3$ month sterling deposit rate in Paris, from OECD Statistical Compendium (series 00EA2). USA: $\quad 3$ month dollar deposit rate in London, from OECD Statistical Compendium (series 00EA1).

\section{Dividend yields}

France: $\quad$ stocks dividend yield, provided by Global Financial Data (syfraym.csv).

Germany: MSCI dividend yield index, provided by Global Financial Data (sydeumym.csv).

UK: $\quad$ UK FT-Actuaries dividend yield, provided by Global Financial Data (dfftasd.csv).

USA: $\quad$ S\&P 500 monthly dividend yield, provided by Global Financial Data (syusaym.csv).

\section{NOTES}

1. In 1989, the newly appointed finance ministe of Germany, Oscar Lafontaine, argued that the USA, Europe and Japan should aim for a return to the Bretton Woods System. The Economist, 1998.

2. A similar result is reported by Alesina et al. (1994).

3. They use two measures of integration, deviations from the ICAPM and from the APT. Cf. Levine and Zervos (1998b).

4. For an overview, cf. Atiyas et al. (1994).

5. Edwards, However, finds a significant reduction in stock market volatility as a result of capital controls (Edwards, 1999).

6. Bekaert and Harvey (2000), Blair (2000).

7. Their results hinge on time-shifted differences-in-differences analysis, assuming that Malaysia was at the same stage of the cycle in the summer of 1998 as Korea in November 1997 and Thailand in July 1997.

8. Keynes (1941).

9. Morgenthau (1994).

10. Eichengreen (1993).

11. Eichengreen (1996). There is ample evidence that such a mechanism was at work in Argentina between 1981 and 1990: Kamin (1991).

12. Obstfeld (1993).

13. For example, many European countries maintained a system under which all foreign transactions, were prohibited unless they had been expressly allowed. Only gradually did they adopt a 'positive' system that allowed all transfers unless forbidden. Cf. Bakker (1993).

14. Countries also experimented with specific currency markets-purchases of foreign securities by residents could only be performed if there was a matching purchase of domestic assets by foreigners. Ireland, the Netherlands, France and the UK used these mechanisms for extended periods (Bakker, 1993).

15. Cf. the careful analysis of alternative dates and specifications in Blair (2000), Bekaert and Harvey (2000).

16. Marston (1993), Obstfeld (1993).

17. Gros (1987), Browne and McNelis (1990).

18. Recent research suggests that correlations have increased dramatically in the 1990s. Cf. Brooks and Catao (2000).

19. Note that simulation studies suggest that effects are more difficult to pick up using returns than dividend yields. Since dividend data for our period is scarce, we choose to use returns, thus biasing our results against our hypothesis of a significnat effect. We 
also tested the sensitivity of our findings if we use an alernative index of global sstock returns (such as the MSCI World Index for 18 countries - cf. Appendix B). We find fundamentally unchaged, large and statistically significant effects of capital account liberalization, and somewhat larger coefficients for the return on the world index. This should not be surprising-the countries used in our study are also all represented in the MSCI World Index, thus biasing correlations upwards. Because of this difficulty, we decided to use US returns instead. Results are available from the author upon request.

20. Jorion and Goetzmann (1999).

21. Table 7 gives the results, which are largely unchanged.

22. There is no significant difference between the results with fixed effects or with a common intercept. Results are available from the author upon request.

23. Typically, we would use dividend yields to control for changes in profitability. However, since the hypothesized effect is said to work through expected changes in profitability, this may not be sufficient. More importantly, data on dividend yields is scarce before 1960 .

24. Cf. also Dooley and Isard (1980), Marston (1993).

25. The reason for using the absolute value of the difference in interest rates is that we are trying to simply measure the extent to which the authorities succeeded in diriving a wedge between the domestic and the international capital market. Since in Germany, the attempts to limit inflows resulted in domestic rates that were higher than for Euro-DM, we need to use absolute values.

26. This is in line with the findings by Levine and Zervos (1998a).

27. I am grateful to Charles Wyplosz for this point.

28. As is well known, inflation tends to have a negative effect on stock returns (Fama and Schwert, 1977). However, since we already control for inflation separately, this is unlikely to drive the results in Tables 13 and 14. Note also that countries facing deflationary pressures under fixed exchange rates - such as the majority of countries in our sample - show the same effect.

29. Note that Marston (1993) found that the Bardepot provisions were more significant than other restrictions.

30. Dooley and Isaard (1980), Bakker (1993).

31. I also experimented with using the excess returns as a dependent variable. However, since the noise to signal ratio is lower than for dividend yields, and because only annual data is available, the effect was inconsistently estimated and/or insignificant.

32. These effects appear particularly large compared to the size of the effects found by Bekaert and Harvey (2000).

33. Note that we are not attempting to provide a full model of industrial output growth. Rather, our model is in the spirit of Bittlingmayer (1998).

34. The impact of revoking exchange controls in 1959 is harder to trace. Evidence at the country level suggests that TFP growth accelerated after 1958 (Sicsic and Wyplosz, 1996).

35. The coefficient on the Quinn index varies considerably by specification, and is at times negative. It is almost never significant. There is therefore only weak empirical support for the idea that greater capital controls regularly led to lower interest rates. Other authors (Wyplosz, 1999), using different data, find slightly larger — and strongly significant - effects. The maximum coefficient on a simple dummy variable for capital controls is 2.69 , while the smallest is 0.95 .

36. If the risk-free rate rises by $1.6 \%$, and the cost of equity falls by $2.8 \%$, the net effect of liberalization for the cost of capital will be positive if the debt is less than $64 \%$ of total capital. For a reduction in the cost of equity by $3.8 \%$, the upper bound on debt is $70 \%$.

37. Eichengreen (1993). He argues that trade discrimination was essential for encouraging trade, and entailed no important negative consequences given the competitiveness of European manufacturers. Thus, 'the EPU offered the best of both possible worlds'.

\section{REFERENCES}

Alesina A, Grilli V, Milesi Ferretti GM. 1994. The political economy of capital controls. In Capital Mobility: The Impact on Consumption, Investment and Growth, Razin A (ed.). Cambridge University Press: Cambridge.

Arteta C, Eichengreen B, Wyplosz C. 2001. On the growth effects of capital account liberalization. Paper prepared for the conference celebrating A. Razin's 60th birthday.

Atiyas I, Caprio G, Hanson J. 1994. An overview of financial reform episodes. In Financial Reform, Hanson J (ed.). Cambridge University Press: Cambridge.

Bakker AFP. 1993. The Liberalization of Capital Movements in Europe. Kluwer: Dordrecht.

Bartolini L, Drazen A. 1997a. Capital-account liberalization as a signal. American Economic Review 87: 138-154.

Bartolini L, Drazen A. 1997b. When liberal policies reflect external shocks, what do we learn? Journal of International Economics 42: $249-273$.

Battilossi S. 2001. The regulation of international banking as an agency problem. The Deutsche Bundesbank and the Bank of Italy under Bretton Woods, 1958-71. Mimeo, London School of Economics.

Beck N, Katz J. 1995. What to do (and not to do) with time-series cross-section data. American Political Science Review 89: 634-647. Bekaert G. 1995. Market integration and investment barriers in emerging equity markets. World Bank Economic Review 9: $75-107$.

Bekaert G, Harvey C. 2000. Foreign speculators and emerging equity markets. Journal of Finance 55: 565-614.

Binder J. 1998. The event study methodology since 1969. Review of Quantitative Finance and Accounting 11: 111-137.

Bittlingmayer G. 1998. Output, stock volatility, and political uncertainty in a natural experiment: Germany, 1880-1940. Journal of Finance 53: 2243-2257.

Blair PH. 2000. Stock market liberalization, economic reform, and emerging market equity prices. Journal of Finance 55: 529-565.

Brooks R, Catao L. 2000. The new economy and global stock returns. IMF Working Paper 216.

Browne F, McNelis P. 1990. Exchange controls and interest rate determination with traded and non-traded assets: the Irish-United Kingdom experience. Journal of International Money and Finance 9: 41-59.

Campbell JY, Lo A, MacKinlay AG. 1997. Tfie Econometrics of Financial Markets. Princeton University Press: Princeton, NJ.

Dooley M, Isard P. 1980. Capital controls, political risk, and deviations from interest-rate parity. Journal of Political Economy 88: $370-384$. 
The Economist. 1998. Off Target.

Edison H, Klein M, Ricci L, Sloek T. 2002. Capital account liberalization and economic performance: survey and synthesis. NBER Working Paper 9100.

Edwards S. 1998. Capital flows, real exchange rates, and capital controls: some Latin American experiences. NBER Working Paper 6800.

Edwards S. 1999. How effective are capital controls? Journal of Economic Perspectives 13: 65-84.

Edwards S. 2001. Capital mobility and economic performance: are emerging markets different? NBER Working Paper 8076.

Eichengreen B. 1993. Reconstructing Europe's Trade and Payments. Manchester University Press: Manchester.

Eichengreen B. 1996. Globalizing Capital. Princeton University Press: Princeton, NJ.

Eichengreen B. 1999. Towards a New International Financial Architecture: A Practical Post-Asia Agenda. Institute for International Economics: Washington, DC.

Eichengreen B. 2001. Capital account liberalization: what do the cross-country studies tell us? Mimeo, University of California, Berkeley.

Eichengreen B, Rose AK, Wyplosz C. 1996. Speculative attacks on pegged exchange rates: an empirical exploration with special reference to the European Monetary System. In The New Transatlantic Economy, Grilli V (ed.). Cambridge University Press: Cambridge.

Fama E, Schwert W. 1977. Asset returns and inflation. Journal of Financial Economics 5: 115-146.

Gielen G. 1994. Können Aktienkurse noch steigen? Gabler: Wiesbaden.

Giersch H, Paque K-H. et al. 1992. The Fading Miracle. Four Decades of Market Economy in Germany. Cambridge University Press: Cambridge.

Gros D. 1987. The effectiveness of capital controls: implications for monetary autonomy in the presence of incomplete market separation. International Monetary Fund Staff Papers 34: 621-642.

Henry PB. 2000. Stock market liberalization, economic reform, and emerging market equity prices. Journal of Finance 55: 529-565.

Jorion P, Goetzmann W. 1999. Global stock markets in the twentieth century. Journal of Finance 54: 953-981.

Kamin SB. 1991. Argentina's experience with parallel exchange markets: 1981-1990. International Finance Discussion Papers 407.

Kaplan E, Rodrik D. 2001. Did the Malaysian capital controls work? NBER Working Paper 8142.

Kaplan J, Schleiminger G. 1989. The European Payments Union. Oxford University Press: Oxford.

Keynes JM. 1941. Post-war currency policy. In The Collected Writings of John Maynard Keynes, Moggridge D (ed.). Cambridge University Press: Cambridge.

Klein M, Olivei G. 1999. Capital account liberalization, financial depth and economic growth. NBER Working Paper 7384.

Krugman P. 1998. Heresy time. Slate 28.9. [available at http://web.mit.edu/krugman/www/heresy.html]

Levine R, Zervos S. 1998a. Capital control liberalization and stock market development. World Development 26: 1169-1183.

Levine R, Zervos S. 1998b. Stock markets, banks, and economic growth. American Economic Review 88: 537-558.

MacKinlay AC. 1997. Event studies in economics and finance. Journal of Economic Literature 35: 3-39.

Marston R. 1993. Interest differentials under Bretton Woods and the post-Bretton Woods float: the effects of capital controls and exchange risk. In A Retrospective on the Bretton Woods System, Bordo M, Eichengreen B (eds). Chicago University Press: Chicago.

Marston RC. 1995. International Financial Integration. Cambridge University Press: Cambridge.

Massad C. 1998. The liberalization of the capital account: Chile in the 1990s. In Should the IMF Pursue Capital-account Convertibility, Dornbusch R. et al. (eds). International Finance Section, Department of Economics, Princeton University: Princeton, NJ.

Morgenthau H. 1944. Pillars of the peace. In Documents Pertaining to American Interest in Establishing a Lasting World Peace: January 1941-February 1946. Army Information School: Carlisle Barracks, PA.

Obstfeld M. 1993. The adjustment mechanism. In A Retrospective on the Bretton Woods System, Bordo M, Eichengreen B (eds.). Chicago University Press: Chicago.

Obstfeld M. 1994. Risk taking, global diversification, and growth. American Economic Review 84: 1310-1329.

Quinn D. 1997. The correlates of change in international financial regulation. American Political Science Review 91: $531-551$.

Quinn D, Inclan C. 1997. The origins of financial openness: a study of current and capital account liberalization. American Journal of Political Science 41: 771-813.

Rodrik D, Rodrik K. 1998. Who needs capital-account convertibility. Should the IMF Pursue Capital-Account Convertibility? Fisher S, Cooper R, Dornbusch R (eds). Princeton, International Finance Section, Dept. of Economics, Princeton University.

Sicsic P, Wyplosz C. 1996. France, 1945-92. In Economic Growth in Europe Since 1945, Toniolo G (ed.). Cambridge University Press: Cambridge.

Stulz R. 1999. Globalization of equity markets and the cost of capital. NYSE Working Paper 99.

Temin P. 1995. The 'Koreaboom,' in West Germany: fact or fiction? Economic History Review 48: 737-753.

Wyplosz C. 1999. Financial Restraints and liberalization in postwar Europe, Mimeo, Graduate Institute of International Studies, Geneva.

Wyplosz C. 2000. Exchange rate regimes: some lessons from postwar Europe. Mimeo, Graduate Institute of International Studies, Geneva. 